\title{
Chapter 7 \\ Technical Universities in Germany: \\ On Justification of the Higher Education and Research Markets
}

\author{
Christian Schneijderberg
}

\subsection{Introduction}

Technical universities (TUs) have a prominent position in the German higher education (HE) landscape. Among the 86 public universities in Germany, 15 bear the name, and 18 can be considered as TUs. Some of the TUs, such as the RWTH Aachen and TU München, are among the most renowned and prestigious universities in Germany. TUs hold a special position in Germany. Not only are there not that many, but they are considered to be of major importance for research and development. TUs are valued as source for educating future engineers, computer, and natural scientists for key industries in Germany and elsewhere (Powell and Dusdal 2017). TUs in Germany do not consider themselves as a coherent group. The big, research-intensive TUs (Aachen, Berlin, Braunschweig, Darmstadt, Dresden, Hannover, Karlsruhe, München and Stuttgart) form the so-called TU-9 Network (see Annex 1). Not included in this network are nine TUs (Chemnitz, Clausthal, Cottbus-Senftenberg, Dortmund, Freiberg, Hamburg, Ilmenau, Kaiserslautern, and Magdeburg). In addition to the vertical stratification among TUs, the big TUs in particular make considerable efforts to set themselves apart and establish their brand on the global higher education and research (HER) markets. Examples of this are the RWTH Aachen building a university in Oman, and the TU München's overseas campus (TUM Asia) in Singapore with its slogan "the entrepreneurial university."

Despite being considered a pillar in the higher education system and the production of scientific knowledge and technology in science, technology, engineering, and mathematical disciplines (STEM), there is surprisingly little literature about TUs in Germany. Among the few publications about TUs is a Festschrift for the 175th anniversary of the Karlsruhe Institute of Technology (KIT). The articles in the edited volume by Kunle and Fuchs (2000) examine the historical development of

\footnotetext{
C. Schneijderberg $(\square)$

University of Kassel, Kassel, Germany

e-mail: schneijderberg@incher.uni-kassel.de
}

L. Geschwind et al. (eds.), Technical Universities, Higher Education Dynamics 56, https://doi.org/10.1007/978-3-030-50555-4_7 
KIT as well as research and teaching in the different disciplines offered at KIT. Other publications use a TU as a case study for explaining the use of quality assurance for strategic management (Münch 2015), and deal with teaching, studying, and key competences transmitted at TUs and their meaning for the world of work (Robertsonvon Trotha 2009). Historians address TUs more from a general technical sciences perspective (e.g., Augustine 2007; Hänseroth and Mauersberger 1998).

As no overview on TUs in Germany could be found, this chapter will present a general picture on research, teaching, and connected knowledge and technology transfer (KTT) of TUs in Germany. To draw a picture of the "form" (Thévenot 1984, 2001; see also Cloutier et al. 2017; Jagd 2011), i.e., the organization, of TUs in Germany, the overview will be based on publicly available information, such as laws, reports, websites, and official statistics. By looking at the situation of TUs as it is, both the stability of the TU-form and the dynamic challenges to the TU-form by the education and research market can be analyzed for the period 2000-2014. This research is guided by the research questions a) "How do publicly set performance indicators empirically construct the form of TUs?" And b) "How does market evolution of education and research products alter the civic-industrial conventions of coordination?" The underlying assumption is that a form, like TUs, is not just there but is continuously constructed by both the civic and industrial order of organizing around meaning, for example, by performance indicators addressing research and teaching. Referring to metrical indications, it is important to be very conscious about the relativism embedded in performance indicators (Boltanski and Thévenot 2006: 341; see also Desrosières 2000).

Both TUs as a form and statistical measures are theoretically and methodologically defined as belonging to the industrial world by Boltanski and Thévenot (2006), in the same way as private companies. ${ }^{1}$ According to Boltanski and Thévenot (2006: 331), research and teaching are considered as public services that are a "compromise between the civic world and the industrial world." Measures, such as performance indicators, are justified "by a concern for the common good of the users" (Boltanski and Thévenot 2006: 331) and with the intention to increase work efficiency. However, the industrial indication of the TU-form conflicts with the public, civic mission of higher education in Germany. The civic form of TUs is constructed by the investment of tax money in the higher education system, for example, for academics, research and higher education infrastructure, and equal access to higher education for qualified citizens. The civic form is also present in the expression of research and higher education purposes in the German constitution, hiring principles secured by laws, and the special position granted to full professors as civil servants for life. Accordingly, this paper argues that the civic-industrial compromise as a composite compromise both generates inner tensions between the civic and

\footnotetext{
${ }^{1}$ The industrial idea seems not to be limited to forms like universities but also to the state as well: Crozier and Friedberg (1980: 141-142) define the French public administration system as "a machine for manufacturing exclusions and privileges - which creates discontentment and malaise; but it is also a distribution mechanism, which spreads its favors around in such a way as to keep complaints below the danger level."
} 
industrial orders and constructs a rather solid fit of the "main conventions of coordination" (Thévenot 2001: 411). The methodological approach of orders of worth by Boltanski and Thévenot (2006) is rooted in political and social philosophy, making it a two-in-one analytical approach to analyzing complex social phenomena. The civic-industrial compromise highlights the advantages of using the orders of worth framework for the exploration of TUs, to systematically study and understand the stable and steady evolution of TUs over time. The analytical orders of worth approach supports the observation of the investments in forms of TUs in Germany by looking at the impact of evaluation, valuation, and valorization practices (Lamont 2012; Vatin 2013). Therefore, this chapter offers a contribution to the study of TUs, using the case of Germany, as well as a theoretical and methodological contribution to how to study TUs and public organizations, i.e., forms, in general.

The development of TUs in the past decades under the governance of numbers expressed in indicators are the focus of the empirical part of this study in Sect. 7.5. In Sect. 7.3 of this chapter, primarily numbers or statistics (industrial order measures) are used for a definition of TUs, which is supported by an analysis of the historical development of TUs in Germany. The idea for the use of data provided by the German Federal Statistical Office (GFSO) to defining TUs was triggered by the theoretical elaboration of the civic-industrial compromise (see Sect. 7.4). Both theoretical and empirical sections help to approach the higher education and research form of TUs based on a solid definition and in an analytically rigorous way. The analytical rigor is based on a theoretical extension of the analytical framework by the situation as it is in the next section.

\subsection{Studying TUs as Investment in Forms via a Situation as it is}

The socio-constructive ${ }^{2}$ orders of worth framework by Boltanski and Thévenot (2006) is based on an explicit mutual dependency of method and theory. Both are not independent but combined in the qualification of subjects and objects during analysis, i.e., analysis and result(s) are not separate steps of the research process (Boltanski and Thévenot 2006: 1-3). Therefore, the analytical categories of each order of worth, and the compromising terms are regarded not just as identifiers, but also as results of analysis (Boltanski and Thévenot 2006: 3-5). The goal of an analysis is to "uncover the common requirements shared by all orders, and to account for a variety of modes of acting that may qualify for public legitimacy" (Thévenot et al. 2000: 239). Legitimacy is rooted in the social affirmation and co-construction of plural orders of worth. Therefore, reflective actors have to "recognize the nature of the situation and apply the appropriate principle[s] of justice" (Boltanski and Thévenot 2006: 146), which belong to one or more orders of worth. The orders of

\footnotetext{
${ }^{2}$ For a pragmatic interpretation see Diaz-Bone $(2011,2017)$.
} 
worth are generated by Boltanski and Thévenot (2006), drawing from political philosophy: civic (Rousseau), domestic (Bossuet), industrial (Saint-Simon), inspiration (Augustine), market (Smith), and opinion (Hobbes).

Like for reflective individual actors, recognition of the nature of the situation appears to be just as important for a form/organization as a collective of reflective actors. ${ }^{3}$ As already pointed out in the introduction, the following analysis of TUs will build on the approach to organizations as investments in form by Thévenot (1984). In an interview, Thévenot explains the core idea of investment in forms as follows: "Making entities more common [...] requires a sacrifice of other potentialities of these entities. If you think of the economic view of investment, the sacrifice is nothing but a cost. If you go more deeply, it appears to be the sacrifice of the immediate market use of money. [...]. When you invest, you sacrifice this possibility for another one. Which is future-oriented, and involves what we [Boltanski and Thévenot 2006] developed later in terms of the industrial worth" (Blokker and Brighenti 2011: 385). Thévenot's (1984: 1) notion of coding for the investment in forms applies to indicators-led setting "of conventions which govern "regulated" communications between people". The research and higher education indicators regulate communications between the state(s) ${ }^{4}$ and TUs as collectives of actors, and, therefore, the individual members of the collective form quantify the qualitative nature of research and higher education services. The coding for evaluation and valorization becomes an expression of valuation (Espeland and Sauder 2007; Lamont 2012; Mau 2018; Vatin 2013). In the end, the indicator-led quantification also allows the construction of money-equivalents for research achievements, student through-put, gender quotas, etc. In this process, the industrial order works as a turning table: The industrial order transforms civic goals and services in calculable products and services. The social construction of higher education and research as marketable is a political and value oriented quantification of qualities, as "there is nothing natural about turning things into monetary equivalents" (Fourcade 2011: 1727).

\footnotetext{
${ }^{3}$ In Boltanski and Thévenot's (2006) On Justification, organizations - however, not as forms - are referred to frequently throughout the book, but neither discussed as a "legitimate form of agreement" (Boltanski and Thévenot 2006: 39) as such nor how an organization is constructed and justified. The omission of organization and of organizations as institutions in the joint work by Boltanski and Thévenot (2006) can be explained by the irreconcilable differences of Boltanski's (2012) domination approach and Thévenot's (1984) approach to institutions and organizations as investments in form. The basic understanding of a form by Thévenot $(1984,2001)$ is similar to other organizational theorists (e.g., Crozier and Friedberg 1980; Powell and Di Maggio 1991; Scott 2014). As such, organizations as ordered forms of coordination can, therefore, be considered as "men build organizations to solve problems that are otherwise intractable" (Crozier and Friedberg 1980: 4).

${ }^{4}$ The spelling 'state(s)' is used to stress the mixed influences of the federal states and the federation on higher education and science politics. Since 2005, the federal states - and not anymore the federation - are responsible for the respective HEIs in their territory. However, indicators, several initiatives, such as the German Excellence Scheme, etc. are jointly funded by the states and the federation.
} 
Prior to the theoretical discussion of TUs as forms in the analytical orders of worth framework in Sect. 7.4, it is necessary to define the situation as the unit of analysis for form analysis. Understanding TUs as a dynamic but stable industrial operation run by the state(s), allows for elaborating on the comprehension of a situation in respect of socially-constructed, institutionalized structures (Honneth 2010). The explicit reflection of institutionalized structures expressed in a situation as it is as unit of analysis enables the elaboration of a definition of TUs in Sect. 7.3.

\subsubsection{Analysis of a Form as a Situation as it is}

Contrary to situated critique and justification among individuals described in $O n$ Justification (Boltanski and Thévenot 2006: 1, 16), the situation of a form of a TU can be perceived from a different perspective. This perspective is based on the understanding of organizations as compromise, composite assemblage or arrangement from different orders (Boltanski and Thévenot 2006: 18). In a later publication, Thévenot (2001) is more specific about the definition of organizations as "form" (Thévenot 2001: 407) and goes on to write about "composite organizations as composite devices" (Thévenot 2001: 410). As a "generalization of coordination" the "investment in form is costly and demands negotiation and material equipment, but the cost may be offset by returns in coordination which depend on the extension of the domain of time and space within which it is accepted" (Thévenot 2001: 407).

For the empirical analysis of TUs in Germany the six orders as "moral and political artifacts" (Thévenot 2001: 410) are analytically differentiated according to a) means of justification in a situation and b) justification by a situation as it is. Common to the justification in time and space in a situation and justification by a situation as it is is the retrospective analysis of a situation based on the orders of worth framework. Contrary to justification in a situation, justification by a situation as it is focuses on forms. ${ }^{5}$ The second difference is that evaluation and valorization resulting in valuation by a situation as it is constructs the dynamic in connecting two or more situations separated in time. Accordingly, the valuation picture generated by linking justification by a situation as it is observes the valuation dynamic and produces insights into the (possible) evolution of valuation practices. The third difference is that justification by a situation as it is considers only the expressions of valuation, for example, provided by indicators and (statistical) reports about the subjects and objects represented by these indicators. Therefore, justification by a situation as it is allows the study of the impact of valuation practices and not the process of evaluating and valorizing, which is the goal of the study of justification (and critique) in a situation. In spite of the quantitative example of indicators, also qualitative empirical material appears suitable for the study of valuation practices

\footnotetext{
${ }^{5}$ At least for the moment, justification by a situation as it is excludes justification (and critique) in a situation between individuals and between several individuals and forms.
} 
over time. Independent of the methodological approach, justification by a situation as it is is about temporary socio-constructive agreements and it disregards the ubiquitous processes of critique and discard of valuation processes.

\subsubsection{Data: Civic-Industrial Measures}

Justification by a situation as it is adds the analytical option for studying investments in form as a composite compromise of agreement - in the presented case of civic and industrial order of worth agreement. The significance of public HER in Germany is expressed by the special status of professors as civil servants, and the security of academic freedom. In article 5, 3, 1 of the German constitution (Grundgesetzt), the state grants freedom of research and of teaching to individual academics. Like all public HEIs, TUs in Germany are public forms, for example, which are to a very large extent tax-funded and charge no tuition fees.

The ideal of 'equality' (civic order) is frequently challenged by issues of efficiency and productivity (industrial order). For the justification of a form by a situation as it is, the annual industrial measures taken are just statistical evidence of the steady stable evolution of (technical) universities in Germany. Accordingly, for an institutionalized social structure, like a (technical) university, situations of conflict and ongoing disputes such as those about performance indicators, do not usually overthrow an established form. Institutionalized structures and orders are only threatened in the case of radical changes. The analysis of the situation as it is as justification of TUs the "requirement of demonstrating proof" (Thévenot et al. 2000: 238) will be done based on an empirical evaluation of the situation of TUs as it is presented in winter 2017/2018. This methodological approach is purely industrial: a systematic comparison of statistical information provided by the GFSO according to performance indicators set by the state(s) (e.g., Bogumil and Heinze 2009). The GFSO offers a provision of information for ministries and politics, but statistics and reports are also available online to the general public. More detailed information about universities and TUs is available from 2006 onwards. As the latest differentiated information about personnel at universities, EF, etc., is available for 2014, the year 2007 was selected for comparison, and, when possible, also the year 2000 thus allowing for an overview of general trends. The pre-2000 GFSO data is even less differentiated. Due to the focus on the civic-industrial compromise other data sources are excluded, such as rankings and ratings which focus on selected products and follow a market order (e.g., Hazelkorn 2015).

To answer the research questions "a) How do publicly set performance indicators empirically construct the form of Tus?" And b) "How does market evolution of education and research products alter the civic-industrial conventions of coordination?", a selective approach is used to avoid writing a book. The focus of analysis will be on Germany, and the interorganizational (Lemieux 2014: 161-162) or interformal comparison of TUs and of TUs and comprehensive universities. Furthermore, the analysis will differentiate between individual Tus, and TU9-members and 
non-members, and between the interformal comparison of TUs and comprehensive public universities. The comparative focus includes the products and services of education and teaching, and the shares of TUs expressed, for example, in numbers of graduates and research $\mathrm{EF}^{6}$

The study of the situation of TUs as it is is separated in two parts. The following section will elaborate and present a definition of TUs in Germany in the year 2018 showing that historically they have a strong connection with the civic-industrial compromise. Contrary to the definition of TUs as a situation as it is in 2018, the second part of the analysis focuses on the situation as it is in 2007 and in 2014, and, in case of data availability in 1994 and in 2000 to observe the impact of the civicindustrial compromise. The civic-industrial compromise is theoretically constructed in Sect. 7.4 and the relative stability and evolution of the civic-industrial compromise is empirically substantiated in Sect. 7.5.

\subsection{Defining Technical Universities in Germany}

TUs are a special type among doctoral granting universities in Germany. Due to the organization of HER across a broader set of disciplines, TUs have more in common with comprehensive public universities than with other specialized HEIs, such as Universities of Education. Indeed, the title Technische Hochschule (Technical Higher Education Institution) or Technische Universität (Technical University) is not protected by state(s) law or trademarked. All HEIs offering HER have to be recognized by the state(s), and this, for example, is expressed in the higher education laws of the German Länder. By law, TUs are treated just like any other public university in Germany, with few exceptions, such as the individual autonomy law for the TU Darmstadt (Hesse 2004).

Historically, universities in Germany are closely connected to the state(s) (Boehm and Müller 1983). In order to meet some practical requirements by the state(s), the foundation of TUs is connected to both industry and economic development. As a result, the foundation of some of the TUs is closely related to local mining and steelproducing industries, as in the Bergakademie Freiberg (translated as: The University of Resources) ${ }^{7}$ and TU Clausthal (Boehm and Müller 1983: 96-97, 142-143). Other

\footnotetext{
${ }^{6}$ The analytical approach excludes from the analysis other types of HEIs in Germany (e.g., UAS) as well as public research institutes such as the Max-Planck Institute and the Fraunhofer Institute. These aforementioned research institutions receive a considerable share of public research and development funding (GFSO 2017b; see Annex 3). Also excluded from the analysis is the international dimension, which encompasses, for example, TUM Asia and international network activities, both on the organizational level (e.g., CESAER (see: http://www.cesaer.org/en/home/) and CLUSTER (see: http://cluster.org/)) and on the level of study programs (e.g., CDIO (see: http:// www.cdio.org/)). In addition, the analysis of transfer products, such as patents and spin-offs, is also excluded. This is due to missing (public) data for the university level.
}

${ }^{7}$ See: http://tu-freiberg.de/en/university/profile (last accessed 2017/11/22). 
TUs, including the University of Hannover in 1831 and the TU Darmstadt in 1836, were founded as "Higher Trade Schools" (Höhere Gewerbeschule). ${ }^{8}$

Additionally, the state(s), and the former royalties, are also key actors in the promotion of technical schools and colleges to the status of a university. In 1869, the Höhere Gewerbeschule Darmstadt was elevated to "Grand-Ducal Hessian Polytechnic School" to provide "full academic, as well as the necessary artistic training, for the technical profession, supported by appropriate practical exercises." In 1877, the polytechnic was renamed as Technische Hochschule zu Darmstadt (Technical Higher Education Institution) and later renamed Technische Universität Darmstadt (Technical University) in 1997. The TU Darmstadt was granted the right to confer doctorates in 1899. The authorities played a crucial role for the TU Darmstadt and for Hannover: in 1879 the school became the "Royal College of Technology" (Königliche Technische Hochschule) and in 1899 Kaiser Wilhelm II granted it, like all TUs in Prussia, the right to confer the Diplom and doctorates (Buchheim and Sonnemann 1990: 231-232). This right to confer doctorates then elevated the status of the college to a status equivalent to that of a university.

But not all contemporary TUs have a bicentennial history. The TU Hamburg was founded in 1978 and was directly conferred university status as a result of the efforts of the city state of Hamburg. The BTU Cottbus-Senftenberg was a 2013 state-driven merger of the BTU Cottbus and University of Applied Sciences (UAS) Lausitz, which were both founded after German unification in 1991 (Brandenburg 2013). None of the 18 TUs identified in this section is located in the Länder Bremen, Mecklenburg-Vorpommern, Saarland, and Schleswig-Holstein.

In addition to historical development, a second seemingly obvious way to identify a TU is by name: RWTH Aachen, TU Berlin, TU Braunschweig, TU Chemnitz, TU Clausthal, TU Cottbus-Senftenberg, TU Darmstadt, TU Dresden, TU Freiberg, TU Hamburg, TU Ilmenau, TU Kaiserslautern, KIT, and TU München. The RWTH Aachen is the only TU that kept the name of a Technical HEI, although in English it is referred to as "RWTH Aachen University" (see Annex 1). However, four universities do not bear TU in their name: Dortmund, Hannover, Magdeburg, and Stuttgart. The universities of Hannover and Stuttgart are members of the TU9 Network of Leading Institutes of Technology in Germany (see Annex 2). Hannover presents a rare case of abandoning the TU name. Indeed, Hannover had the name TU for only a short period of time from 1968 - in that year the "College of Technology" became the Technical University - to 1978. In 1978, seemingly fond of name engineering, and after integrating the college of education, the TU Hannover became the University of Hannover and then the Gottfried Wilhelm Leibniz Universität Hannover, in 2006. ${ }^{9}$ The latest case of name engineering was in 2018 with the TU Hamburg-Harburg becoming the TU Hamburg.

\footnotetext{
${ }^{8}$ This and all of the following references in this paragraph are also taken from: https://www.tudarmstadt.de/universitaet/selbstverstaendnis/profil_geschichte/geschichtetu/thema_geschichte_ k6.en.jsp (last accessed 2017/11/22).
}

${ }^{9}$ See: https://www.uni-hannover.de/en/universitaet/geschichte/stichworte/ (last accessed 2017/11/22). 
Taking into account the third university not bearing the name TU, its historical development has to be considered in regarding it as a TU. The University of Magdeburg was founded in 1953 as Hochschule für Schwermaschinenbau Magdeburg (literal translation: HEI for construction of heavy equipment Magdeburg) and received the status of technical HEI in 1961. The technical HEI Magdeburg was awarded the status of a TU in 1987. In 1993, after German unification, the TU merged with the teacher training college and the Academy of Medicine, and renamed to Otto von Guericke University Magdeburg. ${ }^{10}$

The only recognized TU never to bear the name TU is the University of Dortmund. Nevertheless, the English version of the Dortmund university website refers to the institution as "TU Dortmund University". ${ }^{11}$ Studies at the University of Dortmund began in 1969 with chemistry. Other STEM-fields were then introduced in the years that followed. Subsequently, economics and social sciences were added, beginning in 1973. ${ }^{12}$ At present, the university also accentuates "a comprehensive program of teacher training for all types of schools." 13

To follow-up on the lead of the disciplinary composition of TUs, the analysis of STEM-fields will be used as a third indicator for defining a TU. As already highlighted, there is no definite way of defining what is a TU and what is not a TU - neither by name and/or historical development. Accordingly, empirical, industrial indicators will be analyzed to look for further patterned characteristics as a way to define a TU.

As this section has shown, the name and/or historical development provide only approximations for identifying TUs. For both categories, too many exceptions exist. To illustrate this point further, four out of 18 institutions do not bear the namesignum of a TU. To look for further categories for defining a TU, the empirical evidence presented in Tables 7.1 and 7.2 will be analyzed in the following section.

\subsubsection{Generation of Empirical Categories for Defining a Technical University}

According to the disciplinary categories of the GFSO (2016a, b), the following discipline groups will be referred to as STEM-fields: mathematics and natural sciences (M\&NS) (disciplines group 04), and engineering (disciplines group 08). Professors employed at TUs as civil servants represent a stable number for

\footnotetext{
${ }^{10}$ See: http://www.uni-magdeburg.de/Universit\%C3\%A4t/Im+Portrait/Historisches.html (last accessed 2017/11/22). In the English version the history is much shorter starting only in 1993 with the founding of Otto von Guericke University Magdeburg and omitting the past in the German Democratic Republic.

${ }^{11}$ See: https://www.tu-dortmund.de/uni/en/Home/index.html (last accessed 2017/11/22).

${ }^{12} \mathrm{See}: \quad$ https://www.tu-dortmund.de/uni/de/Uni/Zahlen__Daten_FFakten/Chronik/Gr_ndung_ und_Aufbau/index.html (last accessed 2017/11/22).

${ }^{13}$ See: https://www.tu-dortmund.de/uni/en/Home/index.html (last accessed 2017/11/22).
} 


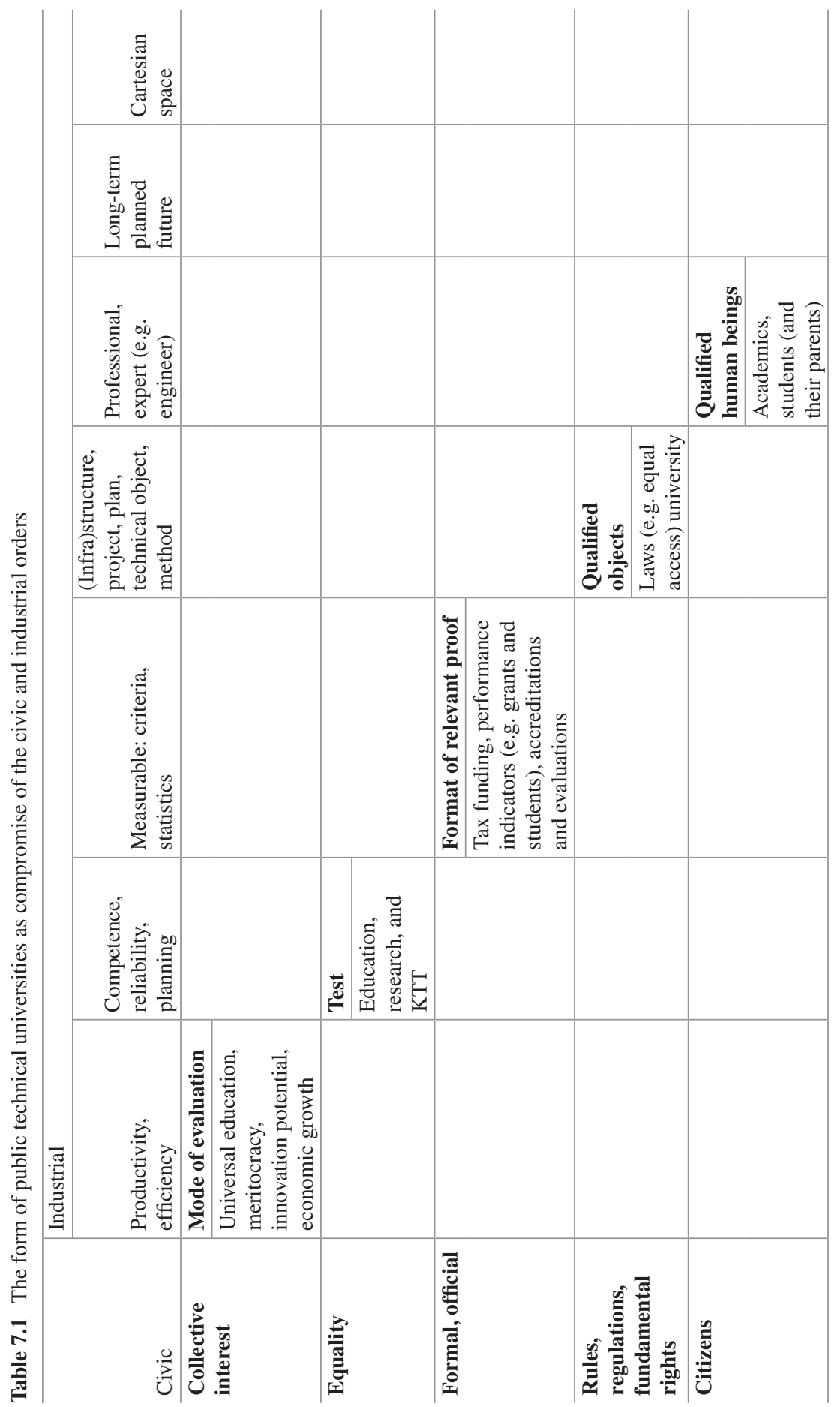




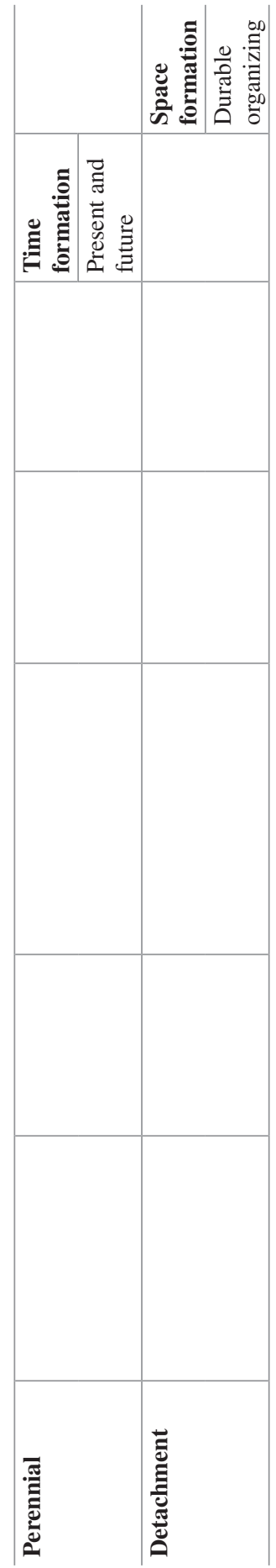


Table 7.2 Categories and expressions of worth of the civic-industrial compromise

\begin{tabular}{l|l}
\hline Categories & Civic-industrial compromise \\
\hline $\begin{array}{l}\text { Mode of evaluation } \\
\text { (worth) }\end{array}$ & Collective interest-oriented productivity and/or efficiency \\
\hline Test & Equality-oriented competence, reliability, and/or planning \\
\hline Form of relevant proof & $\begin{array}{l}\text { Formally and/or officially defined measures (e.g. criteria and indicator } \\
\text { led statistics) }\end{array}$ \\
\hline Qualified objects & $\begin{array}{l}\text { Rules and regulations led (infra)structure, methods, projects, planning, } \\
\text { and/or technical objects }\end{array}$ \\
\hline Qualified humans & $\begin{array}{l}\text { Fundamental rights, respect and collective policies support by } \\
\text { professionals and/or experts }\end{array}$ \\
\hline Time formation & Perennial and long-term planned future \\
\hline Space formation & Detached Cartesian Space \\
\hline
\end{tabular}

counting. ${ }^{14}$ When comparing professorships, the number of professorships in engineering is considered a primary predictor with those in M\&NS a secondary predictor. This is especially the case when looking at the outlier of TU Hamburg with only 9 professorships in M\&NS (GFSO 2016a). Disregarding the outlier bearing the name TU, there is a mean average empirical proportion of no more than 1 to 1.6 (with a median average proportion of 1 to 1.3) of professorships in engineering or M\&NS at TUs under the condition of the existence of no less than 37 engineering professorships at a university.

The description of commonalities and differences among TU9 (see Annex 4, Table 7.6) and non-TU9 universities (see Annex 4, Table 7.7) has to consider exceptions of defining characteristics. For example, all TU9 universities are bigger than non-TU9 universities according to the number of professors. The exception is the University of Dortmund with 302 professors. However, the University of Dortmund, as well as the University of Magdeburg, is not as specialized in STEM-fields as other non-TU9 universities bearing the name TU. The three largest TUs, RWTH Aachen (professors $\mathrm{n}=488$; academic staff $\mathrm{n}=6056$ ), TU Dresden (professors $\mathrm{n}=558$; academic staff $\mathrm{n}=5198$ ) and TU München (professors $\mathrm{n}=483$; academic staff $\mathrm{n}=5996$ ) account for about the same number of professors and almost twice as many academic staff as all non-TU9s together (professors $\mathrm{n}=1481$; academic staff $n$ = 9237). RWTH Aachen and TU München were awarded the title of University of Excellence" 15 in the first and second round of the German Excellence Scheme; the TU Dresden was awarded that title in the second round. The title, awarded to the TU Dresden in the second round, was possibly in response to KIT

\footnotetext{
${ }^{14} \mathrm{At} \mathrm{TUs} \mathrm{in} \mathrm{arts,} \mathrm{humanities,} \mathrm{and} \mathrm{social} \mathrm{sciences} \mathrm{the} \mathrm{average} \mathrm{ratio} \mathrm{is} \mathrm{one} \mathrm{professor} \mathrm{to} \mathrm{four} \mathrm{academic}$ staff, in M\&NS the ratio is one to seven, in engineering one to ten, and in medicine and health one to seventeen. Altogether, in 2015, in HEIs in Germany only $19 \%$ of scientific staff are in the rank of a professor, in 1995 it were 25\% (GFSO 2016a, b).

${ }^{15} \mathrm{See}$ : https://www.wissenschaftsrat.de/en/fields-of-activity/excellence_initiative.html and http:// www.dfg.de/en/research_funding/programmes/excellence_strategy/index.html (last accessed 2017/11/24).
} 
dropping out. Additionally, it may have been in an effort to not to overly represent TUs in the Universities of Excellence scheme - with three out of eleven institutions being TUs.

Obviously, TUs have a clear STEM-field focus. However, TUs are not exclusively STEM-field forms. Professors in STEM-fields account for an average of 71\% (both professors and academic staff) of the scientific staff at TUs. A certain number of professorships in social sciences (including economics and law) are to be found at all of the 18 TUs. ${ }^{16}$ The proportion of professors in STEM-fields varies considerably by size of TUs. A further indicator of the number of professors in STEM-fields is if the TU is able to offer medicine and health subjects. At smaller TUs, the proportion of professors in STEM-fields is, on average, much higher. The TU Kaiserslautern, for example, has $86 \%$ of professors in STEM-fields, with $90 \%$ at the TU Clausthal, which is the smallest TU according to the total number of professors. Due to a comparatively large medical and health faculty at the RWTH Aachen, professors in STEM-fields only account for $61 \%$ of all professors. The ratio is also lower at TUs without the TU in the university name. At the University of Hannover, for example, academics in STEM-fields account for $62 \%$ of all faculty and for $57 \%$ at the University of Dortmund. Stuttgart remains an exception among the non-TU name bearing universities with $81 \%$ of all professors belonging to STEM-fields.

\subsubsection{Definition of a Technical University in Germany}

It is worth noting at this point, the special case of the University of Magdeburg in the sample. The University of Magdeburg appears to be the most conflicting case when deciding if it belongs to the special realm of TUs or not. Summing up on the seven characteristics identified for the definition of a TU the situation as it is in case of the University of Magdeburg is presented as follows:

1. Recognition by state(s): The University of Magdeburg is recognized as a public university by the law of the Land of Saxony-Anhalt $(2010$ : $\$ 1,1,2)$.

2. Name of a TU: The University of Magdeburg does not bear the name of a TU.

3. History as technical higher school and/or HEI before being recognized as a university: This characteristic applies for the University of Magdeburg.

4. Number of professorships with an engineering priority, i.e. minimum number of professorships in engineering: At the University of Magdeburg there are 52 professorships in M\&NS, and 49 in engineering. Among the non-TU9 there are three TUs with fewer engineering professors: TU Clausthal (37), TU Freiberg

\footnotetext{
${ }^{16}$ The selection of the $18 \mathrm{TU}$ cases is not without doubt or saying there could be other TUs in Germany. There is quite number of universities in Germany which are, according to number of academics, strong in M\&NS but not in engineering or vice versa. For example, the University of Erlangen-Nürnberg has a rather large number of academics in both M\&NS (professors $n=158$; academic staff $n=1062$ ), and engineering (professors $n=80$; academic staff $n=899$ ); nevertheless, academic personnel in MNS, and engineering accounts only for $41 \%$ of all academics.
} 
(38), and TU Chemnitz (44). Referring to these three TUs, the minimum threshold of engineering professorships is approximately 40. As for all industrial measures, the number of professorships is subject to alteration. This applies to the empirically derived categories 4, 5, 6 and 7 .

5. Proportion of professorships in engineering to professorships in M\&NS: Referring to the number of professorships in characteristic 3, the proportion of professorships is 1 (in M\&NS) to 1.1 (in engineering), and way above the average mean of 1 to 1.6 or the average median of 1 to 1.3 of professorships in M\&NS to professorships in engineering or vice versa.

6. About $60 \%$ or more professors in STEM-fields at a HEI: The minimum threshold of approximately $60 \%$ of professors in STEM-fields is set by, for example, the University of Hannover (62\%) and RWTH Aachen (61\%). The sample of 18 TUs, highlight the TU percentage of STEM-field professorships would be an average of $71 \%$ and above. At the University of Magdeburg, only $47 \%$ of the total number of professorships belongs to STEM-fields. Weighing up the medical and health fields, i.e., not counting the medical faculty and the ratio of professors in M\&NS, engineering rises from $47 \%$ to $57 \%$. This is the same proportion found at the University of Dortmund, which, unlike the University of Magdeburg does not have medical and health faculty. The importance of STEM-fields in research and education provides a much broader offer than the name TU suggests by, referring only to technical scientific fields.

7. Professorships in social sciences (including economics and law): The University of Magdeburg has 31 professorships in social sciences. The biggest number of social science professorships is found at the TU Dresden $(n=63)$ and the least at TU Clausthal $(\mathrm{n}=8)$.

There is a strong likelihood that more and possibly better characteristics for identifying TUs will be found in the future. Projecting the seven characteristics on to the University of Magdeburg shows that a single characteristic is not enough, but rather a number of characteristics have to be considered for defining a TU. According to the empirical evidence, of the seven characteristics, two in particular seem to be not mandatory for defining a TU: Characteristic 1 the name of a TU, as shown by the exceptions of the universities in Dortmund, Hannover, Magdeburg, and Stuttgart; and characteristic 2 a history as technical higher school and/or HEI before being recognized as a university as, for example, in the cases of the BTU CottbusSenftenberg and TU Hamburg show.

In addition to the explicit exceptions to characteristics 1 and 2, the empirically generated characteristics are challenging. Among the seven identified characteristics, in particular, the numerical characteristics 3 (number of professorships with engineering priority), 4 (proportion of professorships in M\&NS to professorships in engineering), and 5 (approximately $60 \%$ or more professors in STEM-fields at a $\mathrm{HEI}$ ) have to be treated with care. However, looking at statistics alone, it may be an opportunity to improve the characteristics for the definition of TUs. For example, raising the number of professorships with an engineering priority (characteristic 3 ) would be particularly relevant to the traditional, but small TUs specialized in 
STEM-fields, such as Clausthal and Freiberg. The STEM-field commonalities of TUs defined by characteristics 3,4 , and 5 have to be amended by the only other indisputable joint feature: all TUs have professorships in social sciences (characteristic 6).

The elaborate definition of a TU in Germany is also a justification for the sample of 18 TUs used in this chapter. The definition of TUs is the first element of the form of TUs. To answer the research question on the influence of the civic-industrial compromise on the form of TUs in Germany, the second element, i.e., the civicindustrial compromise will be empirically generated based on the compromise of the civic and industrial orders.

\subsection{TUs and the Civic-Industrial Compromise}

\subsubsection{Theoretical Generation of the Civic-Industrial Compromise}

"A compromise suggests the possibility of a principle that can take judgments based on objects stemming from different worlds [or orders] and make them compatible. It aims at a common good that transcends the two different forms [or orders] of worth in presence by including both of them: promoting 'techniques of creativity'." (Boltanski and Thévenot 2006: 278).

The "bridges" (Thévenot 2001: 412) between the industrial and civic orders are built based on all TUs in Germany being public forms. To generate the civicindustrial compromise, a categorical matrix is created (see Table 7.1). Focusing on the categories in the diagonal of the matrix, the core words of the civic and industrial grammars of worth are used to identify core elements (Boltanski and Thévenot 1999: 241). In the box 'mode of evaluation', the industrial worth of productivity and of efficiency finds a compromise with the civic worth of collective welfare by balancing the striving for innovation and economic growth and potential universal access to TUs for those qualified. TUs are supposed to respect the civic ideal of equality when their competences and reliability is put to the test in the delivery of the education and research services. With HER being a public good in Germany, the 'form of relevant proof' can be defined with the measurable amount of tax money spent on HER and the formal, equal definition of research indicators, such as grants and EF. The qualified objects of the civic-industrial compromise are the form of the TU as such, and laws defining access to studies respecting equal citizens' rights, general rules for hiring academics, etc. Laws in particular also define the expertise required from academics as professionals doing research and teaching in TUs, and potential students as qualified human beings to attend a TU.

According to the seven categories explained by Thévenot et al. (2000: 241), the compatibility of the civic and industrial orders is most obvious in the 'time' and 'space formation'. Both the civic and the industrial order for example, have a 'long 
term', durable approach to build 'infrastructures', 'invest' in staff and machinery, organize the operation of research and teaching, etc. Whereas, for example 'equality, is a permanent goal of the civic order, the long-term perspective of the industrial order is expressed in its aim to keep subjects ('qualified human beings') and objects working, and the 'proof' that both do is "grounded in a temporal regularity, the methodic repetition of measurement" (Boltanski and Thévenot 2006: 211).

As the civic-industrial compromise is defined as a composite compromise, i.e. an achievement of boundary work (Lamont 2012), it is considered similar to the composite situation of the "competitive public service" (Boltanski and Thévenot 2006: $278)^{17}$, for further analysis the civic-industrial compromise is combined according to the categories presented in Table 7.2.

Generally, the civic-industrial compromise shows a good mediating fit in all categories. The categories-led composition of the civic-industrial compromise is not without obvious friction. An example of this friction is academic professionals and/ or other TU/university experts (industrial order) being required to act, at least, as much as in their civic and as in their domestic capacity, i.e., with respect to 'fundamental rights respect and support of collective policies'. The composite fit of the civic-industrial compromise appears to be much less conflict loaded than, for example, compromises of the civic and market order (e.g., in category 'qualified human beings': 'equal citizens' vs. 'customers and consumers') or compromises of the industrial and market order (e.g., in category 'qualified objects': 'infrastructure' vs. 'freely circulating goods and services'). In addition, compared to the 'short-term and flexibility goals' of the market order (Thévenot et al. 2000: 241) the composite fit of the civic-industrial compromise appears to be much less conflict loaded in the category 'time formation'.

The compromise of the civic and industrial order of TUs bridges certain conflicts by adopting them. For example, based on the NPM-"doctrine" (Power 1999: 93), the idea of 'equality' (civic order) are part of the 'efficiency and productivity measures' evaluated via audits and performance indicators (industrial order), such as number of female and international students. As a theoretical consequence, the potential of conflicting situations of the civic and industrial order with other orders is altered. The different nature of compromises by the civic and industrial order with other orders will be explained by focusing on challenges by the market order (products of research and teaching). As part of the civic-industrial compromise, the industrial order becomes part of the evaluation - of both 'test' and 'form of relevant proof' - of competitive public services offered by TUs, which Boltanski and Thévenot (2006) defined as a compromise of the civic and market order.

\footnotetext{
${ }^{17}$ Boltanski and Thévenot (2006) define the competitive public service as a compromise of the public service (civic order) and competition (market order).
} 


\subsubsection{Research and Teaching as Products (Market Order) from the Perspective of the Civic-Industrial Compromise}

The long-term and durable operations of TUs according to the civic-industrial compromise are continuously scrutinized regarding the cost (mode of evaluation) of its products by the market order. As Thévenot (2001: 416) acknowledges, the detachment of goods from people - and the domestic order - is particularly difficult in the case of the marketable goods being services, such as offering research expertise in KTT and teaching students. In Germany, the market competitiveness ('test') of degrees and study programs of TUs is measured rather indirectly, for example, money ('relevant proof') spent per student per degree and average duration of studies. The latter is a perfect example of an ideal short-term ('time formation') marketrelated compromise by the civic-industrial compromise.

Education and research are considered the products of a "so-called Fordian or mass production system" (Boltanski and Thévenot 2006: 333). In face of the NPMdoctrine, the civic 'mode of evaluation', 'collective interest' and 'test' of 'equality' are frequently challenged by industrial order expressions of 'efficiency and productivity' and 'reliability and planning'. This challenge is softened by the uncompromising 'mode of evaluation' ('collective interest-oriented productivity and/or efficiency') 'test' ('equality-oriented reliability and planning') of the civic-industrial compromise. But the quality image based on comparisons of numerical differences of performance indicators (Espeland and Sauder 2007; Heintz 2016), such as student intake and graduates, acquisition of competitive EF, TUs supported by German Excellence Scheme are not only market references intended to influence the (public) opinion order. The (growing) influence of the market order on the civic-industrial compromise is very much present in the entire public accountability of the political economics of public HER offered by TUs, and universities in general.

\subsection{The Civic-Industrial Compromise and the Form of Technical Universities in Germany}

\subsubsection{On Justification of Higher Education}

Going industrial on German HER and TUs, i.e., analyzing the statistics available on expenditures on research and teaching, EF generated, etc., means a reduction of complexity and expression of worth in numbers. Boltanski and Thévenot (2006: 43) define money as being a universal numbers reference used for abstraction in a market-based polity: "money is the measure of all things, and thus constitutes the form of evidence" (Boltanski and Thévenot 2006: 202). Money represents only a very coarse point of reference for the civic engagement in public HER (market 'form of relevant proof'). More differentiated, market-oriented indication according to the civic-industrial compromise is provided by looking at the products of higher 
education, i.e., diploma, teachers/state, bachelor and master exams. The presented measures appear to be referencing the defined teaching load of professors and academic staff aiming for collective interest productivity (see Table 7.2). The rising investment of the state(s) in higher education to assuring its 'perennial and long term future' ('time formation') match the rising cost of higher education products.

The political economy of higher education is very present when looking at the indicators of average duration of studies and tax money spent per degree. Comparing the years 2007 and 2014, the average duration of studies is rather stable (GFSO 2008, 2015; see Annex 5). The relative stability of the duration of studies makes the increase of tax money spent even more noticeable. Most striking are the increases in humanities and social sciences, and the comparably moderate increases of costs of engineering degrees.

TUs are, in general, urged by the Länder to use tax money efficiently ('mode of evaluation'), in the same way as other public universities. A further indicator used for TUs is student drop-out rates. Drop-out rates, i.e., university bachelor students not continuing to study a subject for multiple reasons, have been reduced in engineering: of students starting in the winter term of 2006/2007 almost half (48\%) dropped-out; this figure reduced to $36 \%$ of those starting in the winter term of $2008 / 2009$ and then dropped to $32 \%$ of the freshmen starting in winter term 2010/2011. For the same years, in M\&NS the drop-out rates were stable at 39\%, which is quite above the average among university bachelors $(35 \%, 33 \%$, and $32 \%$ ) (Heublein et al. 2017: 264). Drop-out rates from master programs are much smaller and further decreasing in engineering from 12\% of beginners in 2010 to $4 \%$ in 2012. For students starting a master program in M\&NS, in the same 2 years, the drop-out rate increased from $5 \%$ to $10 \%$, which is still below average of the overall master students' drop out of 11\% (2010) and 15\% (2012) (Heublein et al. 2017: 268).

An industrial number just as relevant for the civic-industrial compromise as well as the market order is the number of TU graduates (see Table 7.3). From 1994 to 2015 , the number of graduates at TUs increased by $138 \%$, whereas the number of graduates at all 76 comprehensive public universities about doubled (from 138,336 to 287,469$)$.

The civic-industrial compromise also pays attention to citizens' equal access of qualified humans and competence development in higher education. Defined indicators are, for example, the number of students and freshmen, and the respective

Table 7.3 Graduates in study fields present at all TUs, including percentage of graduates in STEM-fields of total, in 1994, 2000, 2007, 2014, and 2015

\begin{tabular}{l|r|r|r|r|r}
\hline & \multicolumn{1}{|l|}{1994} & \multicolumn{1}{l|}{2000} & \multicolumn{1}{l}{ 2007 } & \multicolumn{1}{l}{2014} & \multicolumn{1}{l}{2015} \\
\hline Engineering & 13,792 & 11,074 & 11,591 & \multicolumn{1}{l}{30,416} & 33,628 \\
\hline Mathematics and natural sciences & 7601 & 6066 & 8843 & 15,069 & 15,622 \\
\hline Social sciences (incl. Economics and law) & 3025 & 4258 & 6262 & 10,002 & 10,077 \\
\hline Total & 29,797 & 27,414 & 34,804 & 67,003 & 71,026 \\
\hline \% STEM-fields of total & 72 & 63 & 59 & 68 & 69 \\
\hline
\end{tabular}

Source: GFSO (2018a) 
percentages of female and male students (GFSO 2017a; see Annex 6). Among the 86 public universities ${ }^{18}$, about $22 \%$ of all students study at TUs. At TUs, female students are still underrepresented with an average of $36 \%$ (compared to $51 \%$ at all public universities). The percentage of females is even lower among international students at TUs (market 'space formation': 'global'). Altogether, the percentage of international students is a slightly higher than at other public universities (18\% to $14 \%$ ).

\subsubsection{On Justification of Increasing Civic/State(s) Spending on Academics Positions}

Effects of the civic-industrial compromise as reactions to market competitiveness ('test'), and the 'short-term', 'flexible investments', especially of private EF in public HER, are visible when observing numbers of academics and the funding sources of positions. EF from business and industry has become less important for the funding of primarily temporary positions for academic staff (GFSO 2009, 2016b; see Annex 7). Comparing the years 2007 and 2014, the proportion of academic staff funded by EF from business and industry declined from $28 \%(\mathrm{n}=35.152)$ to $7 \%$ $(\mathrm{n}=12.915)$. Unfortunately, no data is available for public comprehensive universities and TUs only.

In between 2007 and 2014 the number of academic staff employed in HEIs on public EF increased by more than $500 \%$. The increase of academic staff numbers in temporary positions is primarily due to the larger amount of civic competitive EF in 2014 compared to 2007. This increase of civic competitive EF can be interpreted as being influenced by the market order referring to competitive public services. For the time being, the sustainability of growing EF, for example distributed via the Excellence Scheme, cannot be evaluated. In the civic-industrial compromise, this could mean a loss of capacity with a long-term planning perspective, which is fundamental for the industrial order (Boltanski and Thévenot 1999: 372-373). However, the overall increase of (temporary) positions both for professors and academic staff is mainly due to civic/basic funding by the state(s). The increase of civic/state(s) funding for academic positions can be interpreted as affirming the commitment to public HER and its contribution to "collective interest productivity" ("mode of evaluation'). At the same time, the civic-industrial compromise controls "costs" (market 'mode of evaluation') by substantially increasing non-permanent positions for academic staff (from $9 \%$ to $32 \%$ ), possibly inspired by the NPM-doctrine.

The industrial numbers game also provides a detailed account of the increasing civic expenditure on HER per student, per academic staff, and per professor (GFSO 2008, 2015; see Annex 8). In the STEM-fields, the expenditure per academic staff and per professor has roughly doubled from 2000 to 2014. Looking at the

\footnotetext{
${ }^{18}$ Classification 13 and 14 of the GFSO.
} 
expenditure per student in engineering, the amount in 2000 and 2014 are at the same level with a temporary high in 2007. Unlike engineering, expenditures per student in M\&NS show a steady increase of costs for the same period. Altogether, expenditures on STEM-fields per student, per academic staff, and per professor are not the highest at universities, this would be in medicine and health fields, but is considerably higher than in humanities and social sciences.

The empirical evidence brings forth the conflicts of the civic-industrial compromise caused by the market order. This shows that the particularity of another order, in this case the market, is both challenging the compromise of the civic and industrial order and contributing to the dynamic boundary work in a compromise of two orders. The contribution and, to a certain extent, the dominance of one order within the civic-industrial compromise, will be theoretically and empirically further carved out in the following section. The background of the discussion of the justification of research is the national market evaluating the competitive public service of research and the global market valuing research excellence reported via bibliometric indictors (Butler 2010).

\subsubsection{Justification of Research in TUs}

While expenditures in HER are increasing, also the amount of EF per academic staff and per professor is increasing. On average, from 2000 to 2014, the amount of EF roughly tripled for each non-professorial academic staff member (henceforth academic staff member) and for professors. The proportion of basic funding and EF in STEM-fields has increased from 2007 to 2014. On average, in 2014, academics in engineering can conduct research with an additional 79 cents for every Euro of civic/basic funding, and in M\&NS with 52 cents for every Euro of civic/basic funding. Compared to academics in humanities and social sciences, the additional money for research in M\&NS is twice as much, and in engineering, even three times as much. Of course, some of that more EF money might be due to the higher costs of materials and machinery in engineering and M\&NS. Nevertheless, looking at public expenditures for research and innovation, the proportion of money spent on academic personnel is about the same in M\&NS and engineering compared, for example, to social sciences. The major difference is the much higher amounts of money invested in engineering and M\&NS, which accounts for 63\% (in 2007) and 62\% (in 2014) of the tax money spent (GFSO 2017b; see Annex 9). Indeed, more civic money in the pot for engineering and M\&NS is, firstly, a competitive advantage for STEM-fields research and secondly for TUs with the STEM-fields focus (see Sect. 7.3.2).

The competitive advantage of TUs in acquiring research EF can be further differentiated by analyzing the size of forms. To do so, the sample of 76 universities was divided into three groups based on the number of professors: small universities with up to 200 professors $(n=23$, including 4 TUs; TUs $=17 \%)$, medium universities with 201-400 professors $(n=31$, including 11 TUs; TUs $=35 \%)$, and large 
universities with more than 401 professors $(\mathrm{n}=22$, including 3 TUs; TUs $=14 \%$ ). Compared to 2014 (GFSO 2018b; see Annex 10, Table 7.9), the results presented for the year 2007 (see Annex 10, Table 7.8) are pre Excellence Scheme time. Among disciplines, the amount of $\mathrm{EF}$ and income generated in medicine, especially by hospitals attached to universities, varies considerably from other disciplines (see Annex 8). To present a more coherent picture regarding sources and amounts of EF, medicine and hospitals will be excluded from further analysis of EF.

Altogether, in 2007, the percentage of private EF (e.g., business and industry, and foundations) accounts for about one third of all EF. The proportion does not vary greatly for either of the years with reference to size of universities: large universities $=29 \%$; medium universities $=31 \%$; and small universities $=34 \%$ ). In comparison to 2007, in 2014 this percentage decreases to about one quarter (large universities $=24 \%$; medium universities $=23 \%$; and small universities $=24 \%$ ). Despite the increase in EF, the proportion of money from private business and industry decreases substantially from 2007 to 2014: At large universities from 23\% to $16 \%$, at medium universities from $24 \%$ to $17 \%$, and at small universities from $21 \%$ to $17 \%$.

The proportional decrease of EF by private sources is mainly due to the substantial increase of EF spending by the civic order. Most striking, is the increase of money spent by the federation and civic EF distributed by the DFG. As in from private sources, EF by the federation and DFG, increased substantially in amounts of Euros. Nevertheless, unlike EF from private sources, particularly EF distributed via the DFG, did not decrease in proportion of the total amount. At large universities, DFG EF accounted for $42 \%$ of EF in 2007 and $43 \%$ of EF in 2014, at medium universities for $34 \%$ and $35 \%$ of $\mathrm{EF}$, and at small universities for $28 \%$ and $24 \%$ of EF. The relative stability of the percentage of DFG EF indicates a shift in spending $\mathrm{EF}$ most obviously with funding long-term strategies of universities in the Universities of Excellence Scheme.

These amounts present a substantial increase of the EF total comparing the years 2007 and 2014. Despite the actual increase of EF, the percentage of EF from business and industry is smaller in 2014 compared to 2007. Particularly for medium sized TUs, the proportion of the total dropped from $29 \%$ to $19 \%$. This percentage drop for medium TUs is mainly due to increasing amounts of $\mathrm{EF}$ acquired from the federation and DFG. Of the DFG EF total, the proportion of EF acquired from the Excellence Scheme is comparably small. The Excellence Scheme seems to favor large TUs (9\% of EF total) compared to medium sized TUs (only 3\% of EF total and small TUs $0 \%$ ). A size effect in the distribution of DFG total EF can also be observed comparing TU9 members and non-TU9 members. TU9 members also seem to be the favorite recipients of EF from business and industry, both in 2007 and 2014.

Comparing the three groups of TUs, the main funding sources of federal funding, of DFG, of business and industry are of differing importance. Compared to a big TU, in 2007 and 2014, the percentage of EF from the federation is twice as high and accounts for two fifths of total EF. Conversely, DFG EF accounts for almost one third of total EF of large TUs and only one tenth at small TUs in 2014. This is a 
drastic reduction in comparison to 2007, when DFG EF accounted almost for one fourth of all $\mathrm{EF}$ (see Table 7.4).

Compared to comprehensive universities, and with very few exceptions, TUs are significantly above average in acquiring research EF in total, and in receiving funding from the main EF sources, i.e. the federation, DFG, and business and industry (see Annex 9). The competition among TUs and comprehensive universities seems fiercest for medium sized forms: the 11 (out of 31) TUs do acquire almost twice as much EF as small (4 out of 23) and large (3 out of 22) TUs. Best equipped for the competition with TUs appear to be large comprehensive universities. In addition to the large amount of tax money spent on STEM-fields research, TUs have a competitive advantage in acquiring EF from business and industry compared to comprehensive universities.

Comparing TU9 and non-TU9 members shows that the size of the institution correlates with amounts of EF (with the exception of one TU9 member). Size effects can also be observed by looking at research excellence money: of the 43 research clusters funded by the Excellence Scheme in 2006/2007 and 2012, ten are at TU9 forms, and only one at the TU Chemnitz. The apparent cascade of competitive advantage of TUs is again supported by the primacy of STEM-fields. Of the 43 clusters, nine from engineering, eleven from natural sciences, 17 from life sciences and only six from humanities and social sciences. ${ }^{19}$

\subsection{Conclusion}

For TUs benefiting disproportionally high from main sources of EF, several explanations and interpretations can be sought, such as being well known (Boltanski and Thévenot 2006: 178ff.; Leahey 2007). The EF money measure cannot be considered as an exclusive sign for (high) quality of research (Laudel 2006), but is also subject to the "Matthew Effect" (Merton 1968) both at the level of the individual scientist, as well as forms. This is a psycho-sociological diagnosis of the workings of science as a social institution. Aiming to foster economic growth via research EF, the civic order represented by the federation in Table 7.4 obviously supports TUs more than comprehensive universities. The focus on STEM-fields seems to be in the 'perennial and long-term interest' ('time formation') of civic-industrial compromise, aiming for 'collective interest productivity and efficiency' ('mode of evaluation'), to assure 'equality-oriented reliability and planning' ('test'), and to 'fundamental rights respecting' and (economic) interest policies supported by '(STEM-)professionals' and '(STEM-)experts' ('qualified human beings'). The states' favorable evaluation of the form of TUs seems to be shared by providers of EF from business and industry.

\footnotetext{
${ }^{19}$ See: http://www.dfg.de/gefoerderte_projekte/programme_und_projekte/listen/index.jsp?id= EXC (last accessed 2017/12/15).
} 
Table 7.4 Disproportionally high share of TUs of main sources of EF and EF in general in 2007 and 2014

\begin{tabular}{l|l|l|l|l|l}
\hline & Year & Business and industry & DFG total & Federation & total \\
\hline \multirow{2}{*}{ Small TUs (share $=17 \%)$} & 2007 & $51 \%$ & $32 \%$ & $36 \%$ & $36 \%$ \\
\cline { 2 - 6 } & 2014 & $55 \%$ & $15 \%$ & $37 \%$ & $37 \%$ \\
\hline \multirow{2}{*}{ Medium TUs (share =35\%) } & 2007 & $61 \%$ & $44 \%$ & $51 \%$ & $55 \%$ \\
\cline { 2 - 6 } & 2014 & $57 \%$ & $45 \%$ & $51 \%$ & $57 \%$ \\
\hline \multirow{2}{*}{ Large TUs (share =14\%) } & 2007 & $40 \%$ & $22 \%$ & $29 \%$ & $29 \%$ \\
\cline { 2 - 6 } & 2014 & $52 \%$ & $19 \%$ & $29 \%$ & $29 \%$ \\
\hline
\end{tabular}

Source: GFSO (2018b)

The indicator-led TU/university external evaluation has a rather different meaning for the form and its academic professionals public research and education services. Answering research question b) "How does market evolution of education and research products alter the civic-industrial conventions of coordination?", the results show how the qualitative to quantitative transformation mechanism of public research and education services is similar to the artificiality of turning damage in nature into money equivalents (Fourcade 2011). However unnatural the turning of things, such as research and higher education into money or indicator equivalents is, it is processing evaluation to valuation. Referring to Simmel, Fourcade (2011: 1728) underscores that "the relationship between subjective and objectified value is not unidirectional but dialectical." Therefore, especially the award of EF stimulates the exchange process of tuning the object "into something highly personal and therefore magnify the value we attach to this object" (Fourcade 2011: 1728). This impact of indicators on individual academics is a pressing research issue (Rijcke et al. 2016). Contrary to the personal reward of EF for individual academics, rising student numbers, student through-put, student drop-out, and other higher education defining indicators turn things - who are actually qualified human beings - and magnify the value indicators attach to this object primarily for the form of TUs and universities in general. Accordingly, the analysis shows that criteria-led standardization measures of evaluation as social constructs of accounting techniques "gain authority in particular social contexts and only make sense in relation to the systems of expertise, social relations, and cultural narratives prevalent in these contexts" (Fourcade 2011: 1728).

The dynamism of social relations and cultural narratives was also observed in the construction of characteristics for defining a TU, which cannot be done by name alone (characteristic 3). TUs have a history as technical higher schools and/or HEIs with reference to trading, mining, heavy industry, etc. (characteristic 2) before being recognized as a university (characteristic 1). In 2017, TUs have a strong focus on engineering, hosting a minimum of 40 professorships in engineering (characteristic 4). More empirically generated parameters are a certain proportion of professorships in engineering to professorships in M\&NS (characteristic 5), the dominance of professors in STEM-fields with about $60 \%$ at a TU (characteristic 6), and that all TUs have professorships in social sciences (including economics and law) 
(characteristic 7). Characteristics 4 to 7 present the outcome sought with research question "a) How do publicly set performance indicators empirically construct the form of TUs?"

The seven characteristics present a picture of the construction of the form of TUs as a mix of historical facts, naming, and publicly set industrial justifications, i.e., performance indicators. The performance indicators set by the civic-industrial compromise co-construct what a TU in Germany is and reassure its competitive advantage, which is closely linked to the focus on STEM-Fields of TUs. The empirical evidence provided in this chapter demonstrates that the form presented as TUs in Germany generally do well on the HER markets - and TU9 members do even better - in respect of the civic-industrial compromise. This is particularly visible when looking at the disproportional share of public and private EF accumulated at TUs compared to other comprehensive universities (see Table 7.4). TUs also benefit from the increase in professorships and increased civic/state(s) funding of academic staff in STEM-fields, and the relatively stable cost per student in STEM-fields. Of course, these empirical trends only hold true for the analyzed period from (1994 to 2000 to) 2007 to 2014 . The knowledge embedded in the interplay of performance indicators and statistics can be regarded as co-constitutive for the legitimacy of the governance of HER. Generally, research literature about Germany provides very little account for judging the legitimacy of performance indicators among academics and HEIs (Orr et al. 2007; Sieweke et al. 2014). However, as shown in this chapter, HEIs (have to) play along and the legitimacy of performance indicator use for HER governance by the state(s) is well covered by the NPM-"doctrine" (Power 1999: 93). The outcomes of the use of performance indicators, such as increasing competition and stratification among universities in Germany, already became visible in analyses of the first round of the Excellence Scheme (e.g., Hartmann 2010; Kehm 2013).

To sum up, the indicators specify the investments in the form of TUs (and other HEIs) as a governance tool. Indicators disclose certain characteristics of research and higher education and support as codes the regulated communication between people and forms. The indications address specific inputs in and outcomes of research and higher education activities, which over the course of time sacrifice other potentialities of research and higher education. According to Thévenot (1984), the sacrifice of other potentialities is also a governance mean to control costs of research and higher education - possibly at cost of research and higher education and university ideals (e.g., Münch 2013; Schimank and Winnes 2000).

The methodological and theoretical focus on the civic-industrial compromise as core for analyzing the interformal level being challenged by the particularity of the market order was an empirical test of a "way of solidifying a compromise" (Boltanski and Thévenot 2006: 278). The civic-industrial compromise in form of a TU is based on "objects composed of elements stemming from different worlds [or orders] at the service of the common good and endowing them with their own identity in such a way that their form will no longer be recognizable if one of the disparate elements of which they are formed is removed. Transformed in this way, the compromise is more resistant to critiques, because it now relies on indivisible objects" (Boltanski 
and Thévenot 2006: 278). As shown in this article, such an indivisible object is the form of a TU based on the civic-industrial compromise. For the competitive public services of HER provided by TUs, the compromise between the higher common principles of the civic-industrial compromise ('organized public service') and the market order ('competition') is enforced.

As empirically shown, with focus on research and higher education this represents the situation as it is organized in the form of TUs. The analytical benefit of the differentiation of a) means of justification in a situation and b) by a situation as it is, lays in the additional option of the theoretically guided analysis of justification with reference to orders of worth. This results in a two-step analytical process making the analysis of moral and political justification in a polity very explicit by identifying the modes of coordination. Admittedly, this analytical approach takes much of the dynamics of justification in a situation (Boltanski and Thévenot 2006: 1). However, looking at historical developments and empirical trends, the somehow static situation as it is also presents a dependency of dynamic characteristics from one static moment in time to another to comprehend and explain the construction of a social reality (Berger and Luckmann 1967) and its conventions of coordination.

Acknowledgements This research did not receive any specific grant from funding agencies in the public, commercial, or not-for-profit sectors. The author wishes to thank Anders Broström, Lars Geschwind, Peter Maassen; Nicolai Götze, Christiane Rittgerott, and Isabel Steinhardt for their very welcome feedback on the different draft versions of the manuscript. The author also wishes to thank Gülden Ugurlu and Meike Vollmar from the German Federal Statistical Office for providing additional data on TUs.

\title{
Annexes
}

\section{Annex 1: TU9 - Excellence in Engineering and the Natural Sciences - Made in Germany}

\author{
TU9 President Prof. Dr. Hans Jürgen Prömel:
}

Technical Universities are drivers of economic growth and they secure employment

TU9 is the alliance of leading Institutes of Technology in Germany: RWTH Aachen University, TU Berlin, TU Braunschweig, TU Darmstadt, TU Dresden, Leibniz Universität Hannover, Karlsruhe Institute of Technology, TU München, University of Stuttgart.

The TU9 Universities are excellent in research: According to the Federal Statistical Office, TU9 members attract a fourth of all third-party funding. In the DFG ranking for research funding in engineering, the TU9 Universities are to be found in the top groups. Nationwide $57 \%$ of all doctorates in engineering are awarded at TU9 Universities. 
Furthermore, TU9 Universities were very successful in the German government's Excellence Initiative. RWTH Aachen University (2012, 2007), TU Dresden (2012), Universität Karlsruhe (TH) (now Karlsruhe Institute of Technology, 2006) and TU München $(2012,2007)$ were awarded the status of "University of Excellence".

TU9 Universities lead the way in teaching: In Germany $51 \%$ of all engineers with a university degree come from TU9 Universities. Ten percent of all students at German universities are registered at TU9 Universities.

TU9 Universities are international: $15 \%$ of the students at TU9 Universities are international students. In addition to that, the Humboldt Foundation's ranking demonstrates how attractive the TU9 Universities are to international scientists.

Further USPs [unique selling points] of TU9

[are not displayed as the further USP are available only in German]

Source: http://www.tu9.de/en/index.php (last accessed 2017/11/22)

\section{Annex 2: Mission Statement by Nine Leading Institutes of Technology in Germany}

All of the TU9 universities have a long tradition to look back on and enjoy an excellent reputation among universities at home and abroad. Founded in the age of industrialisation, they have played a significant part in the development of engineering science ever since. Their scientific potential, range of courses and student numbers have grown continuously over a period of almost 200 years. This common ground forms the basis of their cooperation in the university association TU9.

Of paramount importance to TU9 is the promotion of science and research in engineering and natural science.

\section{TU9 fulfils this aim by:}

- strategically coordinating and positioning scientific development at technical universities in Germany,

- staging scientific events,

- supporting young scientists and students,

- cooperating with the federal states of the respective universities, scientific organisations and organisations promoting science, 
- cooperating with the State Rectors' Conferences and the German Rectors' Conference (HRK),

- cooperating with industry and business to promote and maintain Germany's international pre-eminence in technology,

- formulating university and educational policies and communicating them,

- cooperating with foreign universities and taking care of scientists visiting German technical universities.

TU9 is especially committed to furthering a positive attitude to technology in society at large.

TU9 is currently focussing on the following topics:

- Quality assurance and accreditation

- Doctorates in engineering

- Funding research and teaching

- Admission of national and international university applicants

- Structural development

- Transition to bachelor/master

- Cooperation with external research centres

- Standardised German tests for international university applicants

- Human resources development

- International matters

\section{The TU9 members co-ordinate their activities}

- when cooperating with national, European and other international organisations

- in international marketing

- in offshore projects, in the form of university start-up ventures or the export of study programmes and structures

- in quality assurance, with great value being placed on the international relevance of quality assurance programmes

- in benchmarking

Source: http://www.tu9.de/tu9/en/1473.php (last accessed 2017/11/22). 


\section{Annex 3: Public Expenditures on Research and Innovation (Table 7.5)}

Table 7.5 Internal Expenditures of scientific organizations of the public sector in 2015 according to groups of organizations and type of organizations

\begin{tabular}{|c|c|c|c|c|}
\hline & 2002 & 2007 & 2014 & 2015 \\
\hline & \multicolumn{4}{|l|}{1000 Euro } \\
\hline $\begin{array}{l}\text { Public Organizations for Sciences, Research, } \\
\text { and Development }\end{array}$ & $2,003,384$ & $2,409,488$ & $3,178,352$ & $3,076,322$ \\
\hline Federal Research Organizations & $1,527,409$ & $1,850,540$ & $2,701,816$ & $2,581,892$ \\
\hline $\begin{array}{l}\text { State- and communal Research } \\
\text { Organizations (excluding Leibniz-Society) }\end{array}$ & 475,975 & 558,948 & 476,536 & 494,430 \\
\hline $\begin{array}{l}\text { Joint Federation and State sponsored } \\
\text { Organizations for Sciences, Research, and } \\
\text { Development }\end{array}$ & $5,551,844$ & $6,536,156$ & $9,620,454$ & $9,760,259$ \\
\hline Helmholtz-Centers & $2,356,756$ & $2,739,532$ & $4,127,556$ & $4,190,320$ \\
\hline Instituts of Max-Planck-Society & $1,132,057$ & $1,289,897$ & $1,821,279$ & $1,831,231$ \\
\hline Instituts of Fraunhofer-Society & $1,046,878$ & $1,319,326$ & $2,060,313$ & $2,084,769$ \\
\hline Leibniz-Society ("Blue List") & 937,214 & $1,107,429$ & $1,507,430$ & $1,546,713$ \\
\hline Academies (ac. to academy programm) & 78,939 & 79,972 & 103,876 & 107,226 \\
\hline $\begin{array}{l}\text { Other Publicly supported not for profit } \\
\text { Organizations for Sciences, Research, and } \\
\text { Development }\end{array}$ & $1,067,391$ & $1,142,272$ & $1,374,108$ & $1,520,133$ \\
\hline $\begin{array}{l}\text { Scientific Libraries and Museums (excluding } \\
\text { Leibniz-Society) }\end{array}$ & 808,074 & 937,085 & $1,129,342$ & $1,189,894$ \\
\hline $\begin{array}{l}\text { Organizations for Sciences, Research, and } \\
\text { Development total }\end{array}$ & $9,430,693$ & $11,025,001$ & $15,302,256$ & $15,546,608$ \\
\hline $\begin{array}{l}\text { Among these: Institutes at Higher } \\
\text { Education Institutions }\end{array}$ & 448,038 & 537,727 & 732,249 & 758,062 \\
\hline
\end{tabular}

Source GFSO (2017b)

\section{Annex 4: Academics (Professors and Academic Staff) According to Disciplines}

For the empirical display in tables, the 18 TUs are separated by TU9 members (see Table 7.6) and non-TU9 members (see Table 7.7). The practical justification of this separation is the fit of the tables on one page each. The analytical justification of this separation allows for drawing a more differentiated picture within the two groups as well as among the two groups of TUs when discussing the orders of worth. 


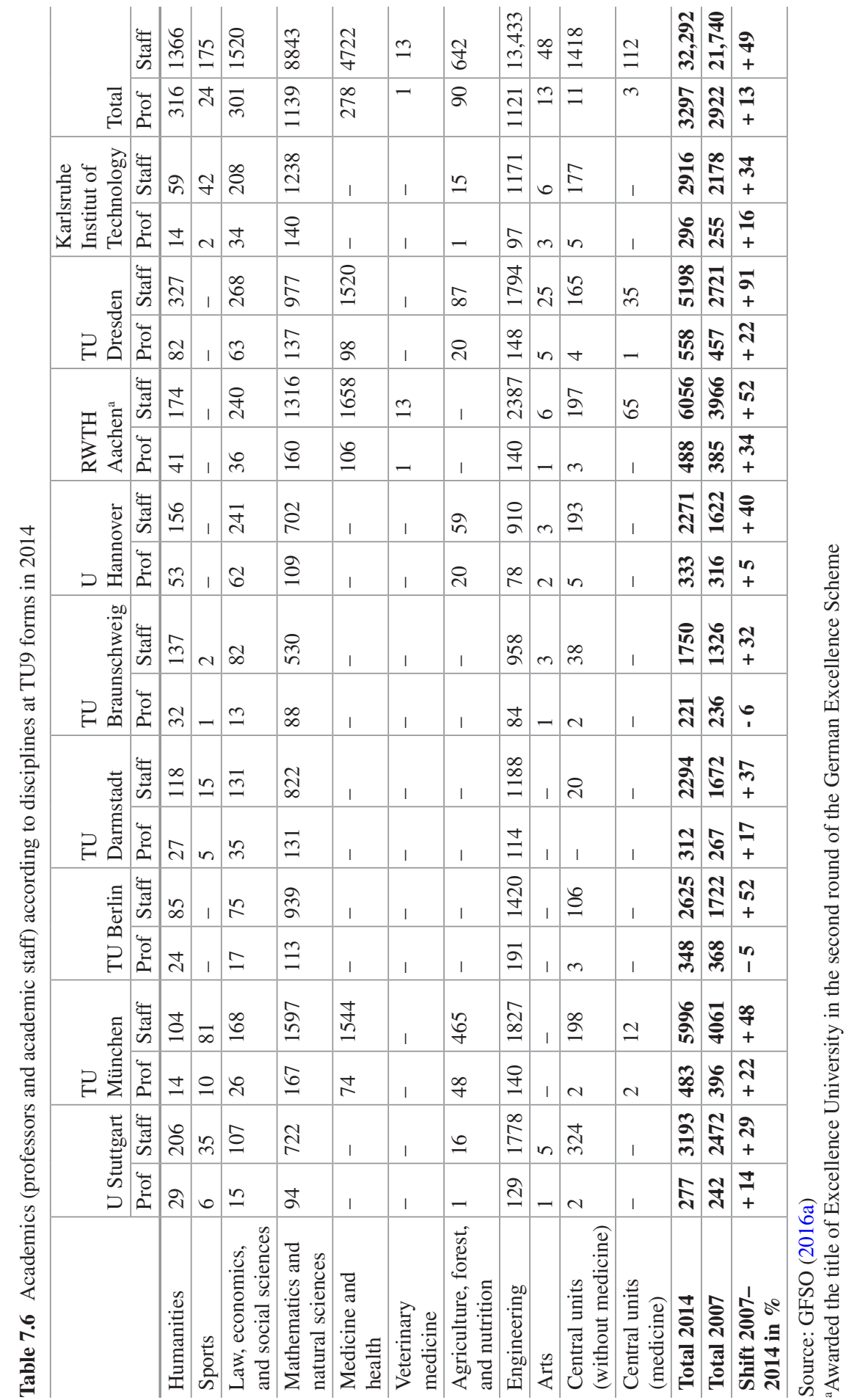




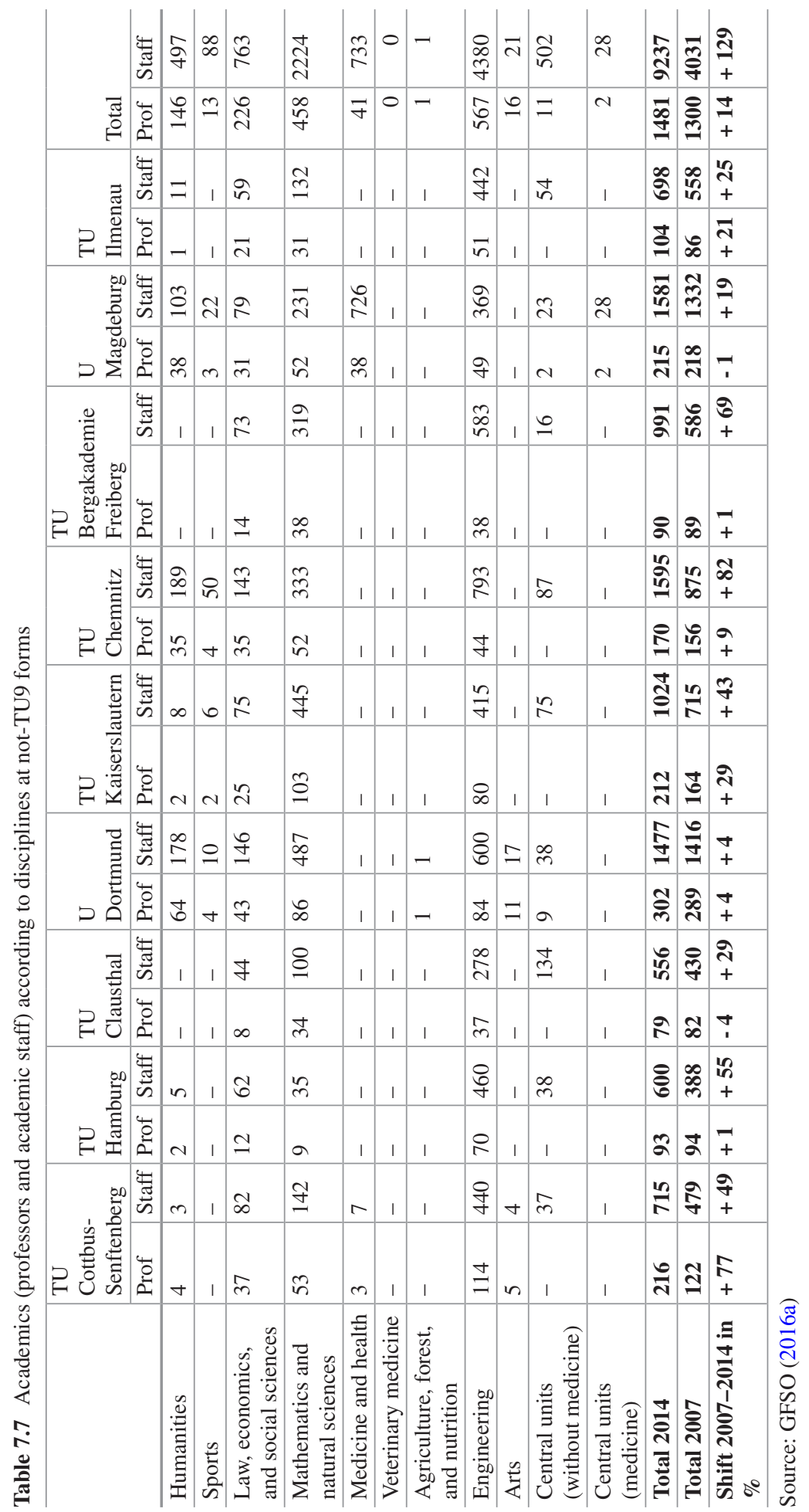




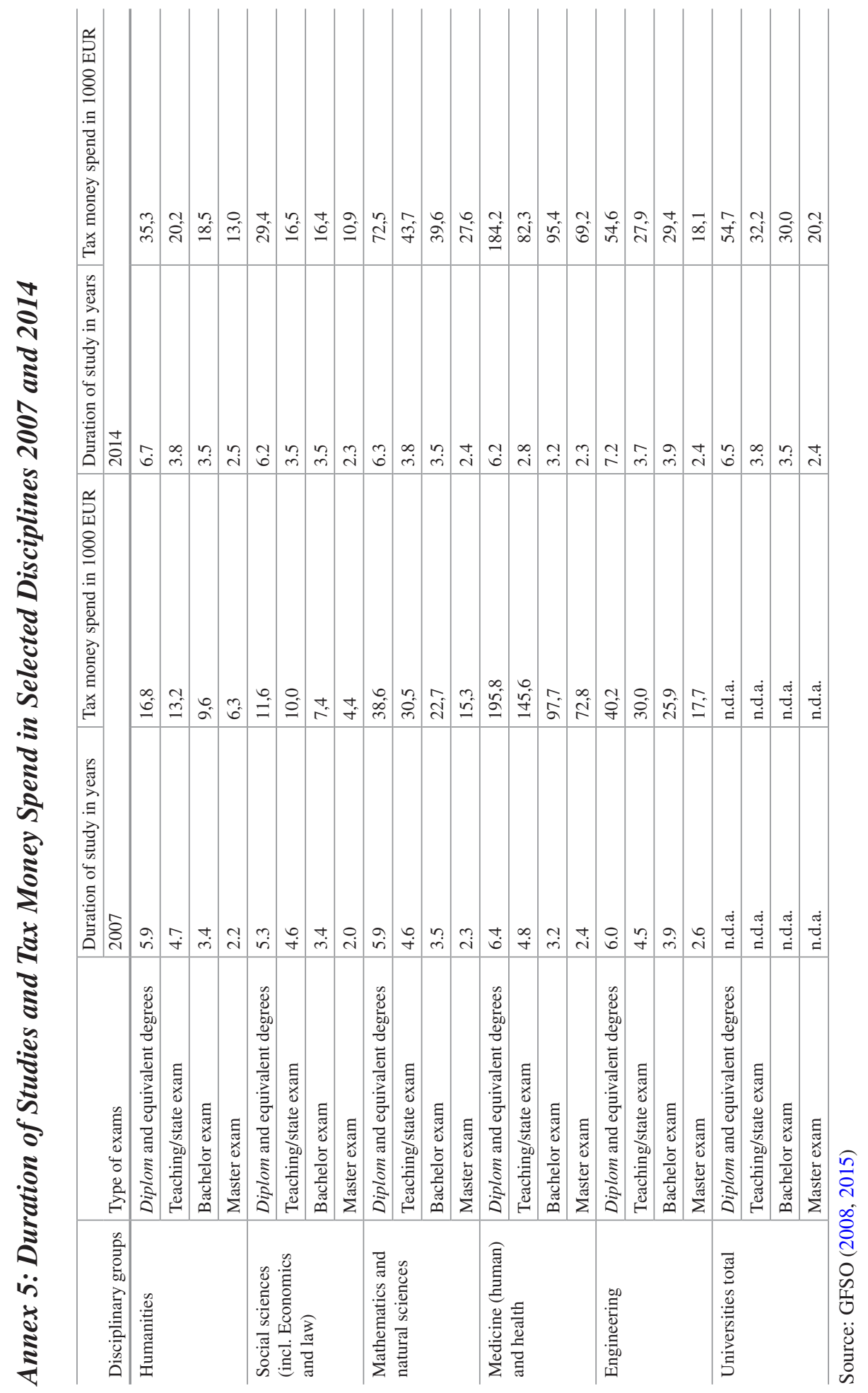




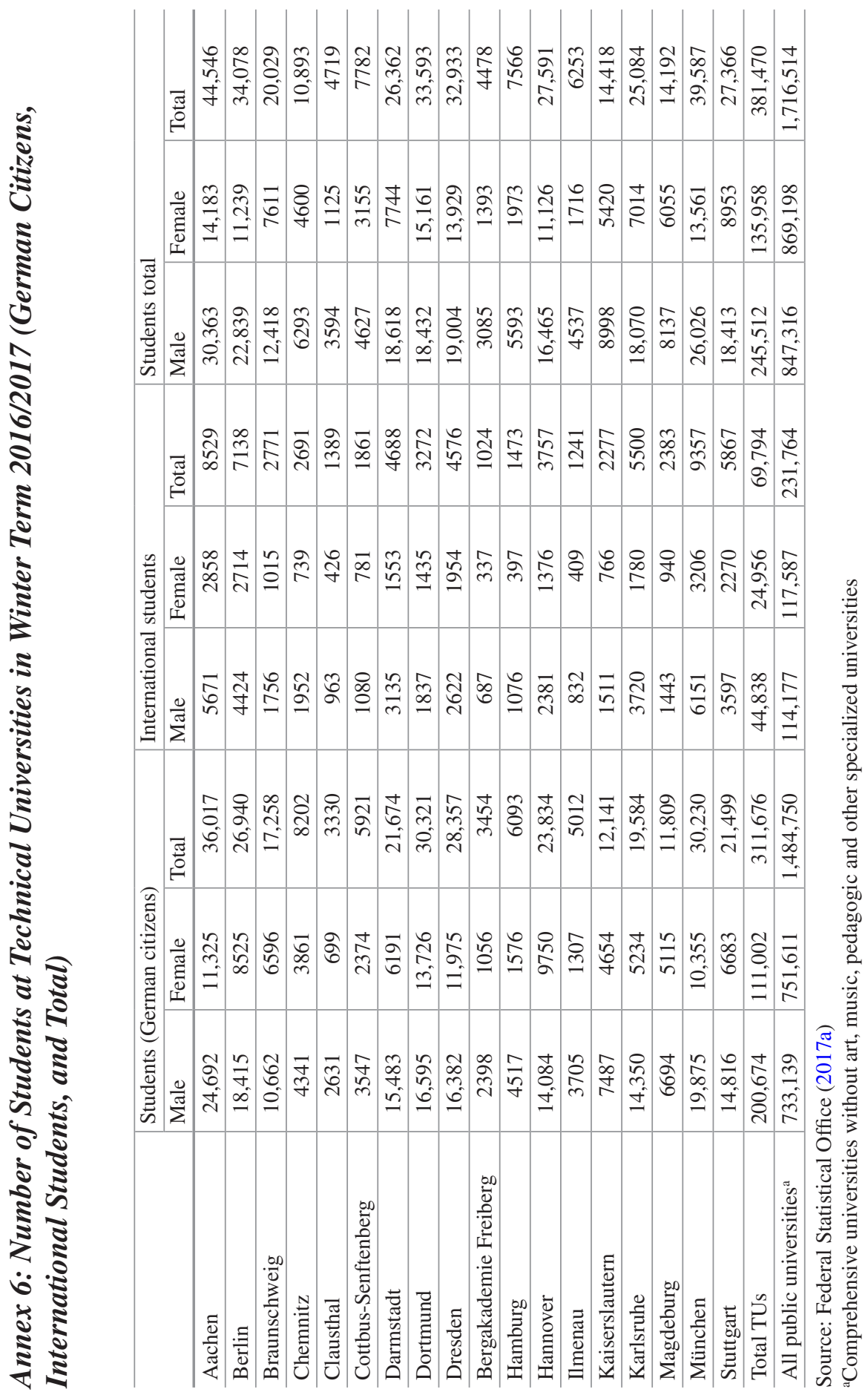




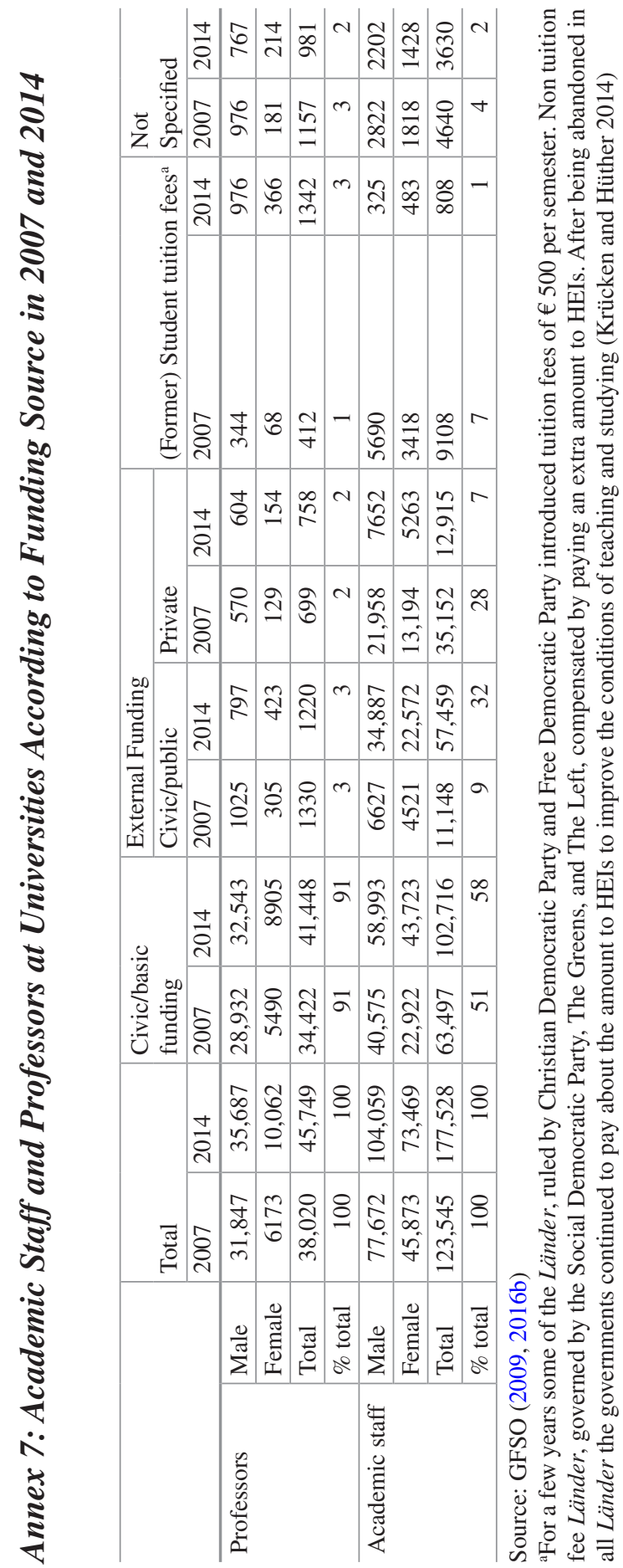



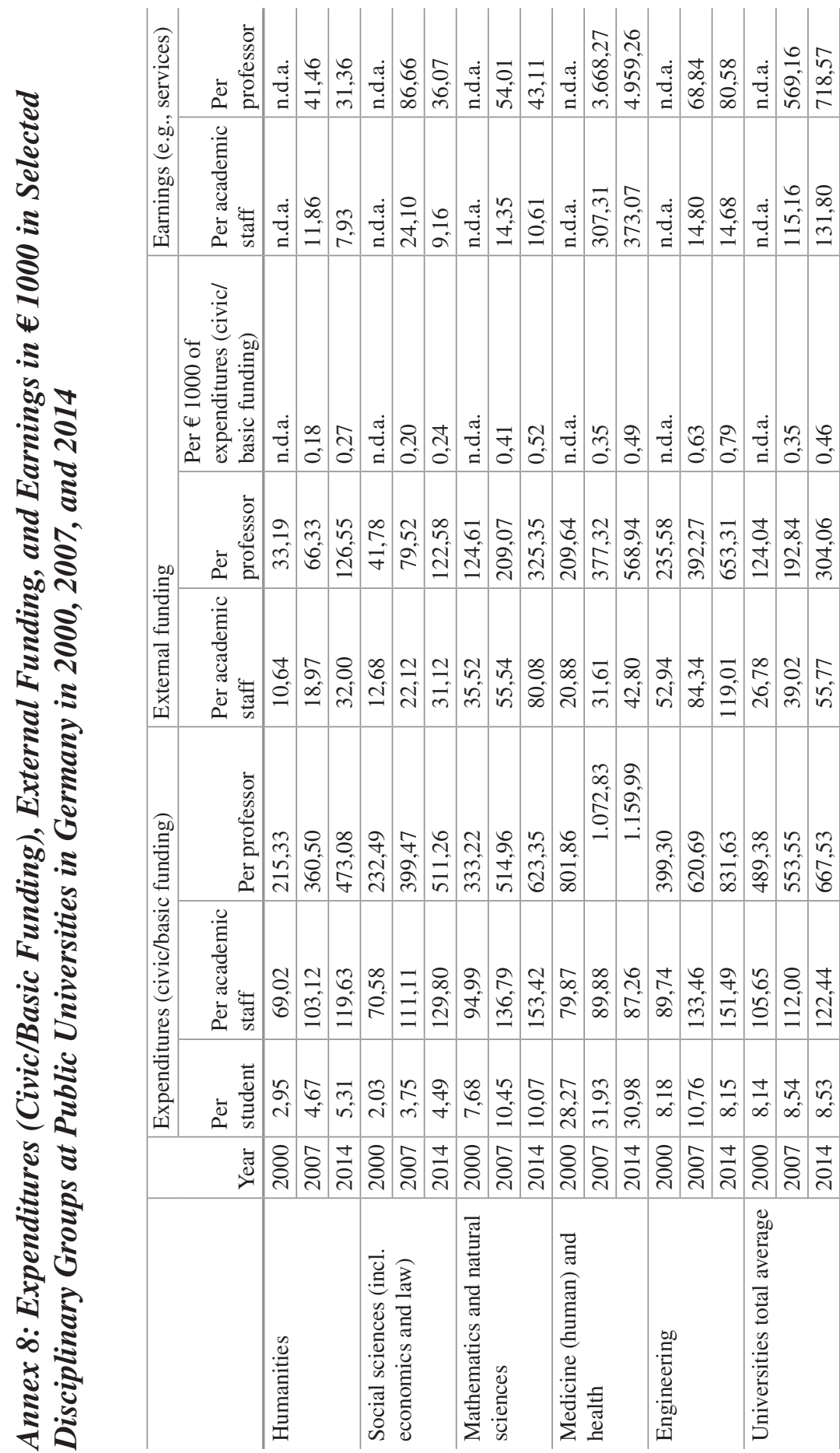

.

फ (2)

旁:

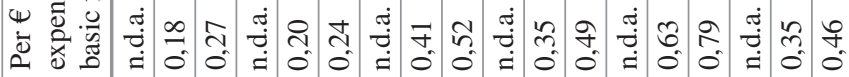

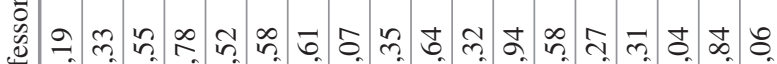
范 衤

范

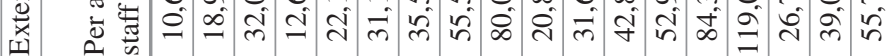

\section{-

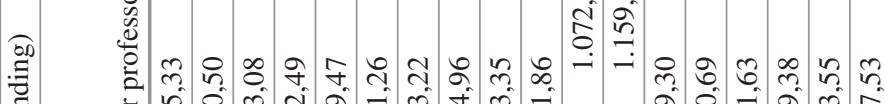

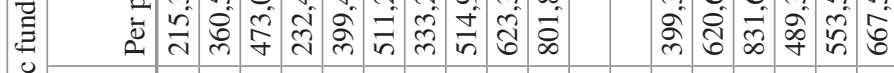

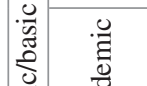

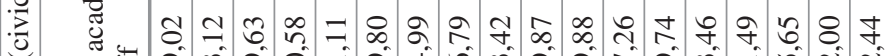

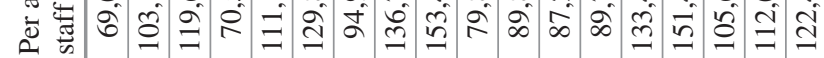

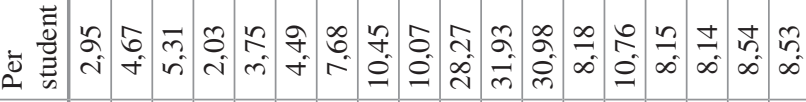 离}

\begin{tabular}{|c|c|c|c|c|c|}
\hline $\begin{array}{l}\text { : } \\
. \stackrel{\Xi}{\Xi} \\
\stackrel{\Xi}{\Xi} \\
\stackrel{\Xi}{\Xi}\end{array}$ & 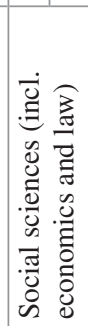 & 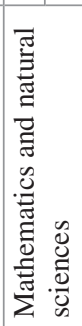 & 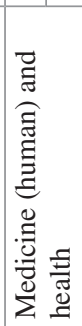 & 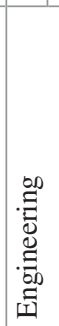 & 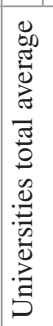 \\
\hline
\end{tabular}




\section{Annex 9: Public Expenditures in 2015 According to Disciplines} and Research Fields

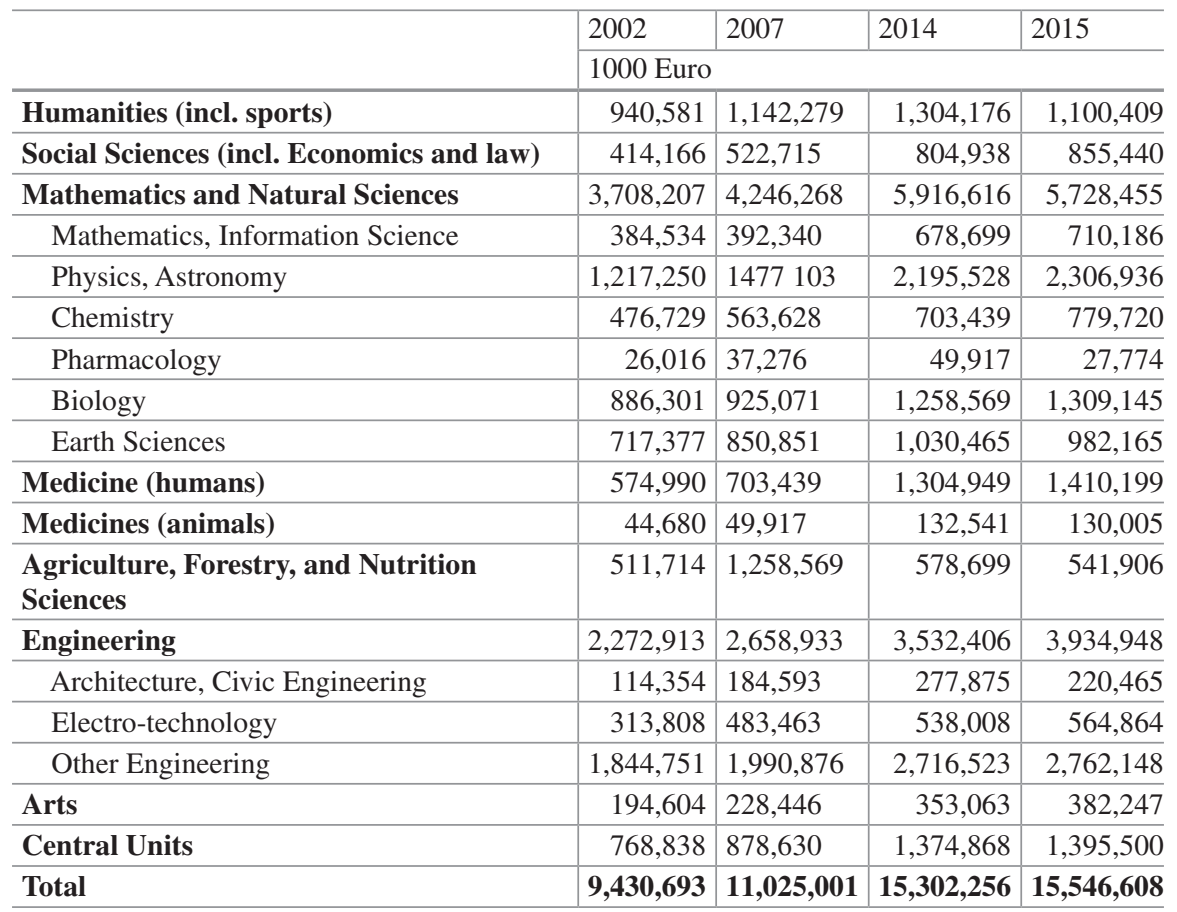

Source: GFSO (2017b) 


\begin{tabular}{|c|c|c|c|c|c|c|c|c|c|c|c|c|c|}
\hline స్తే & $\begin{array}{l}2 \\
\hat{2} \\
0 \\
0 \\
0\end{array}$ & $\mid \begin{array}{l}\tilde{2} \\
\hat{\sigma} \\
\overline{0}\end{array}$ & \begin{tabular}{l}
0 \\
$\infty$ \\
$n$ \\
\multirow{2}{n}{} \\
-
\end{tabular} & \begin{tabular}{l}
$\infty$ \\
$\infty$ \\
$\infty$ \\
\multirow{7}{*}{} \\
$f$
\end{tabular} & & 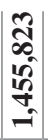 & $\frac{\pi}{\frac{I}{80}}$ & $\begin{array}{l}\text { J } \\
\text { mु. } \\
\underline{6}\end{array}$ & 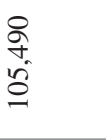 & 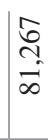 & & & \begin{tabular}{l} 
D \\
N \\
\multirow{1}{*}{}
\end{tabular} \\
\hline 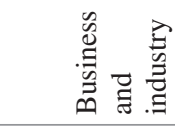 & $\begin{array}{l}8 \\
n \\
\infty \\
\infty \\
n\end{array}$ & $\begin{array}{l}\hat{\sigma} \\
\hat{0}\end{array}$ & $\begin{array}{l}\text { o. } \\
\text { in }\end{array}$ & है & $\overline{\text { ले }}$ & 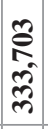 & $\frac{\infty}{0}$ & $\frac{\mathbb{N}}{\mathrm{N}}$ & $\begin{array}{l}\bar{\delta} \\
\stackrel{\Delta}{\Delta} \\
\vec{d}\end{array}$ & $\begin{array}{l}\tilde{} \\
\infty \\
- \\
-\end{array}$ & $\begin{array}{l}\tilde{N} \\
\infty \\
0 \\
\end{array}$ & $\frac{N}{\stackrel{N}{6}}$ & 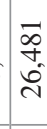 \\
\hline 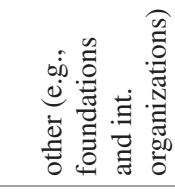 & 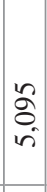 & $\frac{\infty}{a}$ & ป̂ & in & 10 & $\begin{array}{l}n \\
\tilde{\sigma} \\
\infty \\
\infty \\
\infty\end{array}$ & 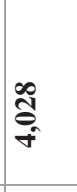 & $\stackrel{n}{f}$ & $\begin{array}{l}+ \\
8 \\
\dot{+}\end{array}$ & $\underset{\mathcal{J}}{\stackrel{N}{\sim}}$ & $\begin{array}{l}\text { fo } \\
\text { in } \\
\text { in }\end{array}$ & 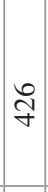 & $\begin{array}{l}\text { I } \\
\text { â }\end{array}$ \\
\hline 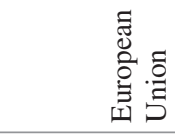 & $\begin{array}{l}\bar{\infty} \\
\stackrel{2}{=} \\
=\end{array}$ & $\begin{array}{l}2 \\
\hat{2} \\
0 \\
0\end{array}$ & $\begin{array}{l}\text { d } \\
\text { in } \\
\text { in }\end{array}$ & 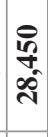 & $r$ & 先 & हิ & 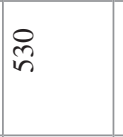 & $\begin{array}{l}\stackrel{?}{\circ} \\
\text { مे }\end{array}$ & $\begin{array}{l}\overrightarrow{\widetilde{\sigma}} \\
\stackrel{\Omega}{\Omega}\end{array}$ & 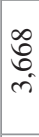 & 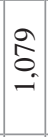 & $\begin{array}{l}\stackrel{m}{m} \\
\dot{\gamma}\end{array}$ \\
\hline 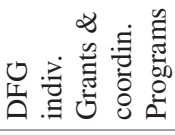 & 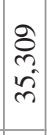 & $\begin{array}{l}2 \\
= \\
=\end{array}$ & $\begin{array}{l}\infty \\
\stackrel{\infty}{2} \\
\stackrel{f}{+}\end{array}$ & 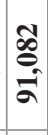 & $\bar{v}$ & $\begin{array}{c}\infty \\
\stackrel{\infty}{m} \\
\\
\end{array}$ & 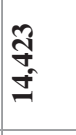 & $\begin{array}{l}\infty \\
\infty \\
\cdots \\
-1\end{array}$ & $\begin{array}{l}\bar{\sigma} \\
\text { فे } \\
\text { N }\end{array}$ & 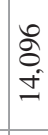 & 흥 & $\begin{array}{l}\infty \\
\stackrel{\infty}{f} \\
\stackrel{f}{f}\end{array}$ & 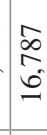 \\
\hline 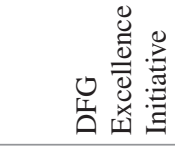 & 0 & 0 & 0 & $\theta$ & 0 & $\theta$ & $\theta$ & 0 & 0 & 0 & 0 & 0 & 0 \\
\hline 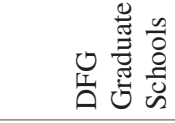 & $\begin{array}{c}\sqrt{2} \\
\text { in }\end{array}$ & I & 0 & $\stackrel{\overrightarrow{\hat{\sigma}}}{\text { ले }}$ & - & $\begin{array}{c}2 \\
\infty \\
\infty \\
\infty \\
\infty \\
0\end{array}$ & $\begin{array}{l}n \\
\frac{1}{2} \\
m\end{array}$ & 0 & $\begin{array}{l}\tilde{n} \\
n \\
i\end{array}$ & 吉 & 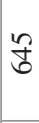 & $\hat{\widehat{ర}}$ & 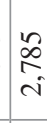 \\
\hline 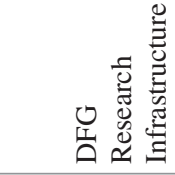 & $\begin{array}{l}0 \\
\tilde{\alpha} \\
\tilde{1}\end{array}$ & $\begin{array}{l}0 \\
\check{2} \\
\check{2}\end{array}$ & $\begin{array}{l}\stackrel{n}{2} \\
\pm \\
\pm\end{array}$ & $\begin{array}{l}\vec{b} \\
\bar{b} \\
F\end{array}$ & 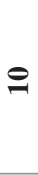 & 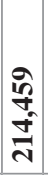 & $\frac{\infty}{\pi}$ & $\mathscr{R}$ & $\begin{array}{l}\bar{m} \\
\stackrel{2}{=}\end{array}$ & $\begin{array}{l}8 \\
\infty \\
\infty \\
\infty\end{array}$ & 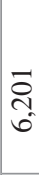 & $\begin{array}{l}f \\
f \\
m\end{array}$ & $\begin{array}{l}\hat{\hat{A}} \\
\text { }\end{array}$ \\
\hline 吾 & $\begin{array}{l}\text { ț } \\
\text { o. } \\
\text { ñ }\end{array}$ & $\begin{array}{l}\hat{\sigma} \\
6 \\
0 \\
0 \\
0\end{array}$ & $\begin{array}{l}n \\
\stackrel{n}{n} \\
\infty \\
n\end{array}$ & 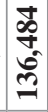 & లె & 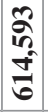 & $\begin{array}{l}0 \\
\text { ลू. } \\
\text { సે }\end{array}$ & $\frac{n}{i}$ & $\begin{array}{l}\frac{1}{8} \\
\text { of } \\
\text { of }\end{array}$ & $\begin{array}{l}\mathscr{2} \\
\tilde{2} \\
\approx\end{array}$ & $\begin{array}{l}\text { y } \\
\text { in } \\
\text { - }\end{array}$ & $\begin{array}{l}8 \\
8 \\
\infty \\
\infty\end{array}$ & $\begin{array}{l}a \\
\infty \\
n \\
\text { â }\end{array}$ \\
\hline 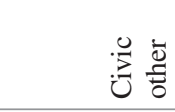 & 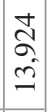 & $\frac{m}{\stackrel{f}{J}}$ & 0 & $\begin{array}{l}\hat{8} \\
\stackrel{0}{0}\end{array}$ & $\nabla$ & 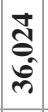 & $\stackrel{\sqrt{6}}{-}$ & ऽ & 0 & $\underset{\tilde{m}}{\tilde{\sigma}}$ & $\stackrel{\infty}{\stackrel{\rho}{f}}$ & ?े & $\begin{array}{l}8 \\
\text { ñ } \\
\text { in }\end{array}$ \\
\hline 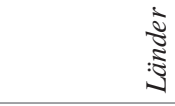 & $\begin{array}{l}8 \\
\delta \\
0 \\
f\end{array}$ & $\begin{array}{l}2 \\
n \\
0 \\
0\end{array}$ & $\frac{7}{6}$ & స్ & $\nabla$ & $\begin{array}{l}\hat{a} \\
\bar{j} \\
\hat{i}\end{array}$ & Fु & $\underset{-1}{8}$ & $\begin{array}{l}\stackrel{0}{\infty} \\
\infty \\
\dot{m}\end{array}$ & $\stackrel{\mathcal{O}}{\mathcal{O}}$ & 0 & $\begin{array}{l}\infty \\
0 \\
i\end{array}$ & $\stackrel{\wp}{n}$ \\
\hline 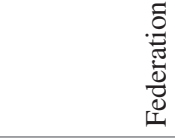 & $\begin{array}{l}2 \\
\hat{\sigma} \\
\hat{\jmath}\end{array}$ & $\begin{array}{l}\tilde{J} \\
\tilde{z} \\
\tilde{d}\end{array}$ & $\begin{array}{l}\hat{f} \\
\text { in. } \\
\text { î }\end{array}$ & $\begin{array}{l}\hat{j} \\
\text { o. } \\
i\end{array}$ & $\approx$ & 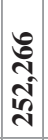 & $\stackrel{0}{=}$ & $\begin{array}{l}\text { Cै } \\
0 \\
\forall\end{array}$ & 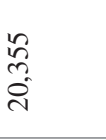 & 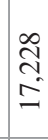 & 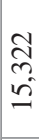 & $\begin{array}{l}\infty \\
0 \\
0 \\
0 \\
0\end{array}$ & $\frac{\sigma}{\sigma}$ \\
\hline & 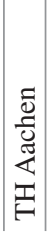 & 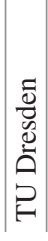 & 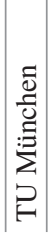 & 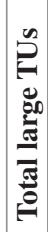 & 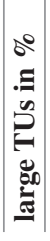 & $\mid$ & 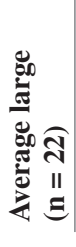 & 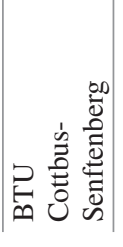 & 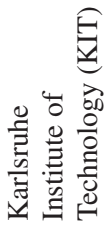 & : & 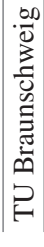 & 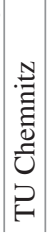 & 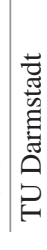 \\
\hline
\end{tabular}


7 Technical Universities in Germany: On Justification of the Higher Education...

\begin{tabular}{|c|c|c|c|c|c|c|c|c|c|c|c|c|c|c|c|}
\hline 8 & $\begin{array}{c}m \\
\dot{q} \\
\dot{n}\end{array}$ & 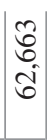 & & 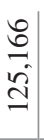 & $\begin{array}{l}00 \\
\infty \\
0 \\
0 \\
6\end{array}$ & $\Xi$ & 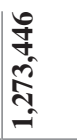 & 疍 & $\begin{array}{l}0 \\
a \\
\tilde{a} \\
\tilde{n}\end{array}$ & & 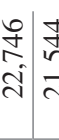 & 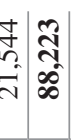 & $\underline{\Xi}$ & 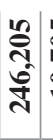 & $\begin{array}{l}n \\
\stackrel{2}{2} \\
\hat{\theta}\end{array}$ \\
\hline $\begin{array}{l}0 \\
i n \\
i \\
r\end{array}$ & $\frac{\dot{v}}{\frac{1}{a}}$ & $\begin{array}{l}\stackrel{\tilde{f}}{\mathrm{j}} \\
\tilde{\sim}\end{array}$ & 年 & $\begin{array}{c}\tilde{g} \\
\dot{f} \\
\tilde{f}\end{array}$ & $\begin{array}{l}\infty \\
0 \\
0 \\
0 \\
0 \\
0 \\
0\end{array}$ & สิ & 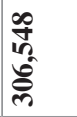 & $\begin{array}{l}\mathscr{\infty} \\
\infty \\
\sigma\end{array}$ & $\begin{array}{l}\approx \\
=\end{array}$ & $\begin{array}{ll}0 & 7 \\
& 7 \\
\infty & 7\end{array}$ & & 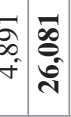 & ले & 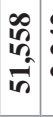 & ป̂t \\
\hline $\begin{array}{l}\Omega \\
\stackrel{2}{i} \\
i\end{array}$ & $\mid \begin{array}{l}n \\
\infty \\
0 \\
0\end{array}$ & $\stackrel{\infty}{\stackrel{\infty}{ \pm}}$ & 这 & $\begin{array}{l}\tilde{v} \\
\tilde{n} \\
-\end{array}$ & 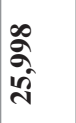 & $\nabla$ & $\begin{array}{l}\text { İ } \\
\text { N̂ } \\
\infty\end{array}$ & $\begin{array}{l}1 \\
0 \\
0 \\
i\end{array}$ & 0 , & $\simeq$ & $0 \frac{1}{4}$ & ホ & - & 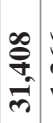 & స్ర \\
\hline ?2 & $\begin{array}{l}0 \\
b \\
+ \\
i\end{array}$ & $\begin{array}{l}n \\
n \\
m\end{array}$ & $\stackrel{ }{\stackrel{0}{-}}$ & $\begin{array}{l}\hat{n} \\
\hat{\sim} \\
\hat{n}\end{array}$ & $\begin{array}{l}\underset{⿱}{\sigma} \\
\vec{b}\end{array}$ & 은 & 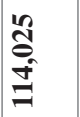 & 冓 & 0 & 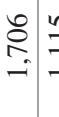 & $\begin{array}{l}= \\
= \\
=\end{array}$ & 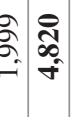 & 10 & $\begin{array}{l}\text { ta } \\
\text { : } \\
\text { dी }\end{array}$ & $\Xi$ \\
\hline$\frac{\Omega}{\sigma}$ & $\frac{t}{2}$ & $\begin{array}{l}\infty \\
\tilde{n} \\
\sigma\end{array}$ & $\begin{array}{l}n \\
n \\
n \\
n\end{array}$ & $\begin{array}{l}\infty \\
\sigma \\
\pm \\
-\end{array}$ & 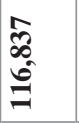 & 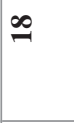 & 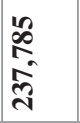 & $\begin{array}{l}8 \\
6 \\
\text { م }\end{array}$ & 0 & 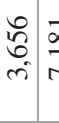 & 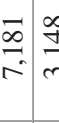 & 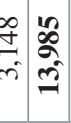 & 은 & $\begin{array}{l}\mathbb{J} \\
\text { ू. } \\
\text { s. }\end{array}$ & $\stackrel{\sqrt{2}}{6}$ \\
\hline 0 & 0 & 0 & 0 & 0 & $\theta$ & $\theta$ & 0 & $\theta$ & 0 & 00 & 00 & 00 & 0 & $\theta$ & $\theta$ \\
\hline $\begin{array}{l}\hat{n} \\
i n \\
i\end{array}$ & 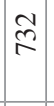 & $\vec{\infty}$ & 吉 & \begin{tabular}{l}
\multirow{J}{0}{} \\
+ \\
- \\
-
\end{tabular} & $\begin{array}{l}\overrightarrow{\vec{\partial}} \\
\text { ले }\end{array}$ & N & 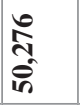 & స్త్ర & $\begin{array}{l}m \\
\tilde{n} \\
m \\
m\end{array}$ & 0 תִ & $\stackrel{\curvearrowright}{\curvearrowright}$ & 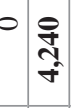 & $\nabla$ & 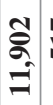 & $\frac{n}{n}$ \\
\hline $\begin{array}{l}\infty \\
n \\
n\end{array}$ & $\begin{array}{l}a \\
\grave{2} \\
\end{array}$ & $\begin{array}{l}\overrightarrow{\tilde{b}} \\
\dot{f}\end{array}$ & $\div$ & $\begin{array}{l} \pm \\
0 \\
0 \\
0\end{array} \mid$ & $\begin{array}{l}\text { Va } \\
\dot{F} \\
\dot{v}\end{array}$ & 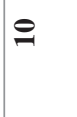 & 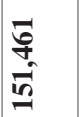 & $\begin{array}{l}\infty \\
\infty \\
\infty \\
+\end{array}$ & $\cong$ & స్ & $\sqrt[3]{2}$ & 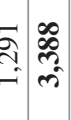 & $\nabla$ & $\begin{array}{c}10 \\
0 \\
0 \\
0 \\
0\end{array}$ & $\stackrel{2}{2}$ \\
\hline$\frac{}{2}$ & $\mid \begin{array}{c}\tilde{n} \\
\stackrel{f}{\sigma} \\
\infty \\
\infty\end{array}$ & $\begin{array}{l}\vec{S} \\
\dot{\partial} \\
\pm\end{array}$ & $\begin{array}{c}\stackrel{\partial}{\sigma} \\
\dot{f}\end{array}$ & $\begin{array}{l}8 \\
0 \\
+ \\
2 \\
i\end{array}$ & $\begin{array}{l}\text { సิ่ } \\
\text { ஸે } \\
2\end{array}$ & లి & 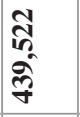 & $\stackrel{\infty}{\stackrel{\infty}{I}}$ & $\begin{array}{c}0 \\
6 \\
m \\
m\end{array}$ & $\begin{array}{ll}n & d \\
n & g \\
n & r\end{array}$ & 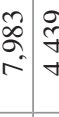 & 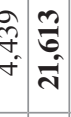 & $\mathscr{N}$ & 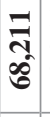 & $\begin{array}{l}\text { ¿े } \\
\text { à }\end{array}$ \\
\hline 它 & $\mid \begin{array}{c}2 \\
\dot{g} \\
\text { n் }\end{array}$ & $\stackrel{2}{2}$ & $\underset{f}{\stackrel{f}{ \pm}}$ & $\begin{array}{l}\hat{f} \\
\text { î } \\
\end{array}$ & 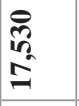 & $m$ & 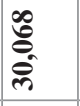 & 종 & 0 & $\frac{m}{n}$ & $0 \Omega$ & $=\stackrel{\sim}{\widetilde{m}}$ & - & 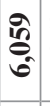 & ֶֻ. \\
\hline 0 & $\overline{\hat{n}}$ & $\stackrel{\Xi}{\mathbb{Z}}$ & $\stackrel{m}{g}$ & 0 & à & N & $\begin{array}{l}\infty \\
\frac{\infty}{\sigma} \\
\infty \\
\text { ì }\end{array}$ & ๙ & 0 & $\begin{array}{ll}\stackrel{\infty}{\sim} \\
\sim\end{array}$ & 00 & 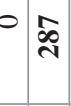 & - & $\begin{array}{l}\stackrel{8}{+} \\
\text { m̂́ }\end{array}$ & 은 \\
\hline $\begin{array}{l}\tilde{J} \\
\text { [. } \\
\text { n. }\end{array}$ & $\begin{array}{l}\mathscr{2} \\
2 \\
0 \\
0 \\
0\end{array}$ & $\begin{array}{l}2 \\
\S \\
\vdots \\
=\end{array}$ & 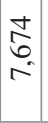 & $\begin{array}{l}\frac{0}{a} \\
\stackrel{n}{\lambda} \\
\hat{n}\end{array}$ & 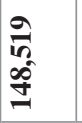 & $\ddot{\sim}$ & $\begin{array}{l}\bar{a} \\
\hat{\bar{~}} \\
\hat{\mathrm{A}}\end{array}$ & $\underset{\infty}{\mathbb{N}}$ & $\begin{array}{c}\overline{0} \\
\infty \\
\infty\end{array}$ & $\begin{array}{ll}n & \bar{c} \\
\infty & \alpha \\
\dot{f} & =\end{array}$ & 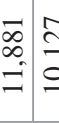 & 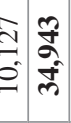 & ? & $\begin{array}{l}\text { लि. } \\
\text { s. } \\
\text { in }\end{array}$ & 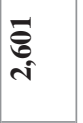 \\
\hline 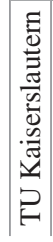 & 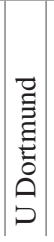 & 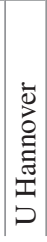 & $\left|\begin{array}{c}0 \\
0 \\
0 \\
0 \\
0 \\
0 \\
0 \\
\Sigma \\
\vdots \\
0\end{array}\right|$ & 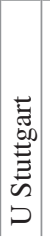 & 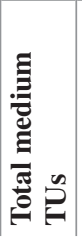 & 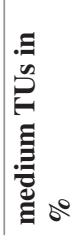 & 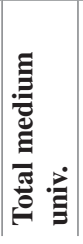 & 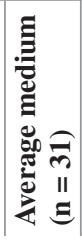 & 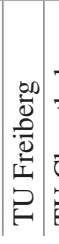 & 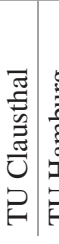 & 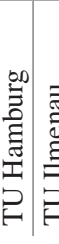 & 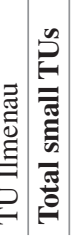 & 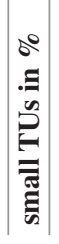 & 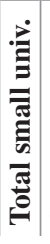 & 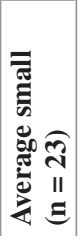 \\
\hline
\end{tabular}




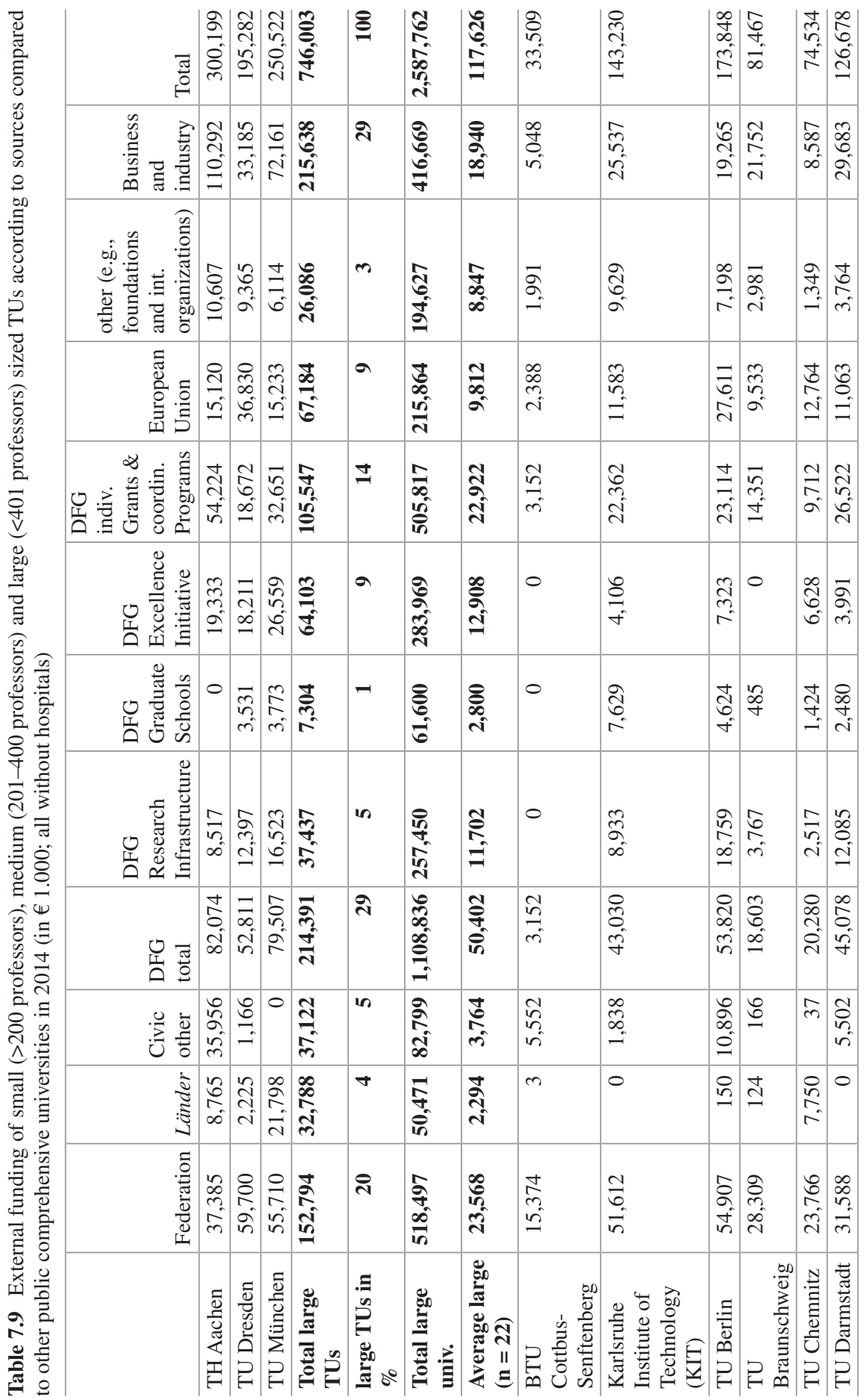


7 Technical Universities in Germany: On Justification of the Higher Education...

\begin{tabular}{|c|c|c|c|c|c|c|c|c|c|c|c|c|c|c|c|c|}
\hline $\begin{array}{l}\bar{\circ} \\
\stackrel{n}{\sigma} \\
\dot{f}\end{array}$ & $\mid \begin{array}{l}n \\
\infty \\
\infty \\
\tilde{b}\end{array}$ & $\left|\begin{array}{l}0 \\
0 \\
0 \\
0 \\
0 \\
0\end{array}\right|$ & 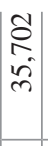 & 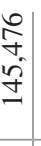 & 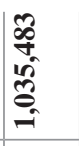 & $\stackrel{\nexists}{\varrho}$ & ฮิ & 递 & $\left|\begin{array}{l}8 \\
0 \\
0 \\
0 \\
8 \\
0\end{array}\right|$ & $\begin{array}{l}m \\
\infty \\
\infty \\
\tilde{n}\end{array}$ & $\begin{array}{l}\dot{f} \\
\infty \\
m\end{array}$ & $\begin{array}{l}\infty \\
\infty \\
0 \\
\dot{y} \\
\forall\end{array}$ & 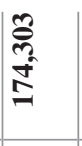 & $\stackrel{\Xi}{\varrho}$ & 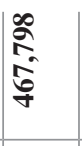 & ले \\
\hline $\begin{array}{l}\stackrel{m}{f} \\
\text { mे }\end{array}$ & $\begin{array}{l}\bar{m} \\
\infty \\
\infty\end{array}$ & $\begin{array}{l}n \\
n \\
n \\
\infty \\
i\end{array}$ & $\begin{array}{l}\bar{a} \\
\sigma \\
\sigma\end{array}$ & $\begin{array}{l}\frac{a}{0} \\
0 \\
\dot{n} \\
m\end{array}$ & 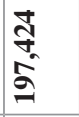 & 2 & $\begin{array}{l}\text { Yे } \\
\text { Oे } \\
\text { लें⿰ }\end{array}$ & 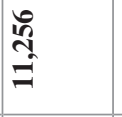 & 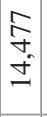 & 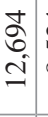 & $\begin{array}{l}\vec{J} \\
\text { ñ } \\
\infty \\
\infty\end{array}$ & $\begin{array}{l}\infty \\
\stackrel{2}{ } \\
\vdots \\
0\end{array}$ & 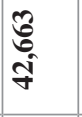 & $\underset{\sim}{\sim}$ & \begin{tabular}{l}
$\infty$ \\
$\infty$ \\
\multirow{+}{*}{} \\
$\mathfrak{N}$
\end{tabular} & $\begin{array}{l}\hat{b} \\
\text { ले } \\
\text { ले }\end{array}$ \\
\hline $\begin{array}{l}\text { ते } \\
\text { mે }\end{array}$ & 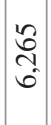 & $\underset{\sim}{2}$ & $\begin{array}{l}\infty \\
\infty \\
- \\
-\end{array}$ & $\begin{array}{l}5 \\
6 \\
i\end{array}$ & \begin{tabular}{l}
$\bar{\delta}$ \\
$\infty$ \\
\multirow{y}{*}{}
\end{tabular} & $\nabla$ & 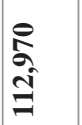 & $\begin{array}{l}\mathbb{J} \\
\text { ले } \\
\text { ले }\end{array}$ & 离 & F & $\begin{array}{l} \pm \\
0 \\
i \\
i\end{array}$ & $\begin{array}{l}\bar{\infty} \\
\stackrel{2}{i} \\
i\end{array}$ & 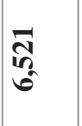 & $\nabla$ & $\begin{array}{l}\text { ปे } \\
\text { In } \\
\text { लि }\end{array}$ & กิ \\
\hline 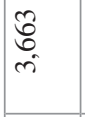 & 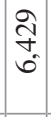 & 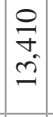 & $\begin{array}{l}\overrightarrow{0} \\
\text { r. } \\
- \\
-\end{array}$ & $\begin{array}{l}\vec{z} \\
\infty \\
i \\
\text { I }\end{array}$ & $\begin{array}{c}\mathfrak{N} \\
\text { Na } \\
\mathfrak{a} \\
\exists\end{array}$ & $=$ & $\begin{array}{l}0 \\
: \\
0 \\
0\end{array}$ & సี & 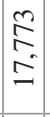 & $\begin{array}{l}\underset{J}{\Xi} \\
\dot{f}\end{array}$ & 守 & $\begin{array}{c}\vec{\nabla} \\
\infty \\
- \\
-1\end{array}$ & $\begin{array}{l}n \\
0 \\
10 \\
10 \\
n\end{array}$ & 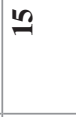 & $\begin{array}{l}\stackrel{8}{+} \\
\text { ñ }\end{array}$ & 文 \\
\hline $\begin{array}{l}\text { 寺 } \\
\stackrel{-}{=}\end{array}$ & $\begin{array}{l}\tilde{\sigma} \\
\sigma \\
\sigma\end{array}$ & $\frac{\infty}{\infty}$ & $\begin{array}{l}\hat{n} \\
n \\
n \\
n\end{array}$ & $\begin{array}{l}\text { సे } \\
0 \\
\hat{\mathrm{D}}\end{array}$ & స్ర్రి & $\simeq$ & 命 & $\frac{2}{2}$ & 0 & 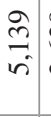 & $\begin{array}{l}\text { స్ } \\
\text { त̂ }\end{array}$ & $\begin{array}{l}\underset{\Phi}{0} \\
\stackrel{f}{+}\end{array}$ & 今̆ & $r$ & 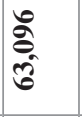 & $\frac{i}{i}$ \\
\hline 0 & త్ & $\begin{array}{l}8 \\
0 \\
\infty \\
-1\end{array}$ & 0 & \begin{tabular}{l}
$\hat{m}$ \\
\multirow{\sigma}{\sigma}{} \\
0
\end{tabular} & 妾 & $m$ & $\frac{m}{\overbrace{0}^{0}}$ & $\frac{1}{2}$ & 0 & 0 & 0 & 0 & $\theta$ & $\theta$ & 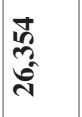 & $\stackrel{0}{\stackrel{1}{2}}$ \\
\hline 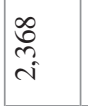 & $\stackrel{尺}{尺}$ & $\begin{array}{l}n \\
\text { aे } \\
\text { in }\end{array}$ & $\overrightarrow{\mathrm{g}}$ & \begin{tabular}{l}
$\vec{\infty}$ \\
0 \\
\hdashline \\
-
\end{tabular} & 气̊ & N & 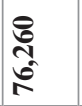 & \begin{tabular}{l}
8 \\
0 \\
\multirow{2}{*}{} \\
in
\end{tabular} & 0 & 0. & 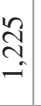 & $\begin{array}{l}\tilde{\delta} \\
\infty \\
- \\
-\end{array}$ & ळ. & N & $\begin{array}{l}\mathscr{\not} \\
\infty \\
\infty\end{array}$ & $\stackrel{\infty}{\infty}$ \\
\hline $\begin{array}{l}\text { f } \\
\text { in } \\
\dot{n}\end{array}$ & $\begin{array}{l}\hat{\infty} \\
\infty \\
\sigma\end{array}$ & $\begin{array}{l}\hat{N} \\
\infty \\
\infty \\
\infty\end{array}$ & $\begin{array}{l}\hat{\widehat{े}} \\
\hat{i}\end{array}$ & 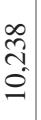 & $\begin{array}{l}\sqrt{n} \\
\text { है } \\
\text { i }\end{array}$ & $\infty$ & 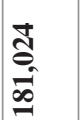 & $\begin{array}{l}\hat{\tilde{N}} \\
\hat{\infty} \\
\text { in }\end{array}$ & 0 & i̊ & $\begin{array}{c}0 \\
\text { in } \\
\text { - }\end{array}$ & 0 & 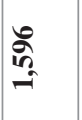 & -7 & $\begin{array}{l}\vec{\partial} \\
\vec{g} \\
\underline{a}\end{array}$ & in \\
\hline $\begin{array}{l}\sqrt[0]{0} \\
2 \\
2\end{array}$ & $\begin{array}{l}\hat{\infty} \\
\dot{0} \\
\stackrel{i}{0}\end{array}$ & $\begin{array}{l}\hat{b} \\
\infty \\
0 \\
\infty \\
0\end{array}$ & $\begin{array}{c}\infty \\
0 \\
+ \\
\infty \\
\infty\end{array}$ & $\frac{n}{\infty}$ & $\begin{array}{l}\vec{\infty} \\
\dot{\infty} \\
\dot{\infty}\end{array}$ & ले & â & \begin{tabular}{l}
10 \\
\multirow{J}{0}{} \\
di
\end{tabular} & 0 & $\begin{array}{l}\stackrel{n}{\sigma} \\
i n\end{array}$ & $\begin{array}{l}\text { ڤ్ } \\
\hat{n} \\
\hat{n}\end{array}$ & $\begin{array}{l}\hat{\alpha} \\
\hat{\sigma} \\
\dot{n}\end{array}$ & 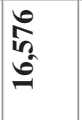 & $\Theta$ & 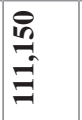 & $\begin{array}{l}\infty \\
\infty \\
\infty \\
+\end{array}$ \\
\hline$\frac{\infty}{m}$ & $\underset{\sigma}{\stackrel{\sigma}{\sigma}}$ & 0 & $m$ & $\begin{array}{l}\stackrel{N}{\sigma} \\
\stackrel{\sim}{i}\end{array}$ & ले & $m$ & $\begin{array}{l}\infty \\
0 \\
0 \\
i=0 \\
i n\end{array}$ & $\stackrel{5}{0}$ & $\bar{m}$ & ڤे & 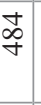 & : & 厄్ & - & $\begin{array}{l}\overline{\text { a }} \\
\infty\end{array}$ & $\stackrel{\infty}{\infty}$ \\
\hline 0 & so & 0 & \begin{tabular}{l}
+ \\
\multirow{6}{*}{} \\
$i$
\end{tabular} & 0 & $\stackrel{\Xi}{\Xi}$ & - & $\begin{array}{l}\hat{n} \\
\text { ले } \\
\text { ते }\end{array}$ & $\stackrel{R}{i}$ & $\stackrel{n}{\sigma}$ & 0 & $\bar{\varrho}$ & $\underset{\infty}{\stackrel{0}{7}}$ & $\begin{array}{l}\text { 范 } \\
\text { a }\end{array}$ & 0 & $\begin{array}{l}\text { n } \\
\text { in } \\
\text { J }\end{array}$ & త్ర \\
\hline 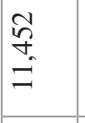 & 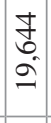 & 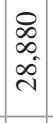 & $\begin{array}{l}\hat{n} \\
\hat{b} \\
=\end{array}$ & 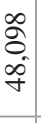 & 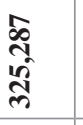 & $\bar{m}$ & $\begin{array}{l}\text { in } \\
\text { in } \\
\text { in } \\
8\end{array}$ & 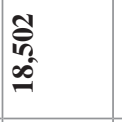 & 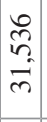 & $\frac{\widehat{\sigma}}{\sigma}$ & 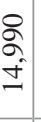 & 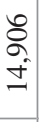 & 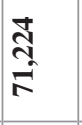 & $F$ & 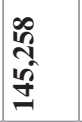 & $\frac{b}{\tilde{n}_{2}}$ \\
\hline 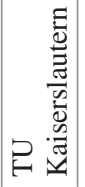 & 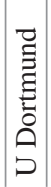 & 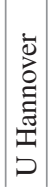 & 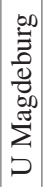 & 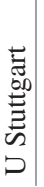 & 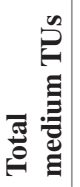 & 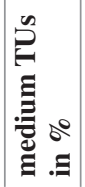 & r & 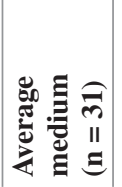 & 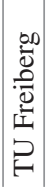 & 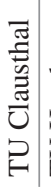 & 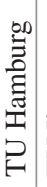 & 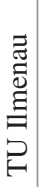 & 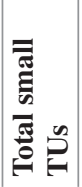 & 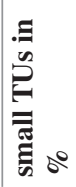 & 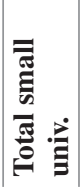 & 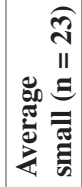 \\
\hline
\end{tabular}




\section{References}

Augustine, D. L. (2007). Red prometheus. Engineering and dictatorship in East Germany (pp. 1945-1990). Cambridge: MIT Press.

Berger, P. L., \& Luckmann, T. (1967). The social construction of reality: A treatise in the sociology of knowledge. London: Penguin Press.

Blokker, P., \& Brighenti, A. (2011). An Interview with Laurent Thévenot: On engagement, critique, commonality, and power. European Journal of Social Theory, 14(3), 383-400.

Boehm, L., \& Müller, R. A. (1983). Universitäten und Hochschulen in Deutschland, Österreich und der Schweiz. Eine Universitätsgeschichte in Einzeldarstellungen. Econ: Düsseldorf \& Wien.

Bogumil, J., \& Heinze, R. (Eds.). (2009). Neue Steuerung von Hochschulen. Eine Zwischenbilanz. Berlin: Sigma.

Boltanski, L. (2012). Love and justice as competences. Cambridge: Polity.

Boltanski, L., \& Thévenot, L. (1999). The sociology of the critical capacity. European Journal of Social Theory, 2(3), 359-377.

Boltanski, L., \& Thévenot, L. (2006). On justification. Economies of Worth. Princeton: Princeton University Press.

Brandenburg. (2013). Gesetz zur Neustrukturierung der Hochschulregion Lausitz (vom 11. Februar 2013), http://www.bravors.brandenburg.de/sixcms/media.php/land_bb_bravors_01.a.111.de/ GVB1_I_04_2013.pdf. Accessed 22 Nov 2017.

Buchheim, L. G., \& Sonnemann, R. (1990). Geschichte der Technikwissenschaften. Basel: Springer.

Butler, L. (2010). Impacts of performance-based research funding systems: A review of the concerns and the evidence, in $O E C D$, performance-based funding for public research in tertiary education institutions. Paris: OECD.

Cloutier, C., Gond, J.-P., Bernard, L., et al. (Eds.) (2017). justification, evaluation and critique in the study of organizations (Research in the Sociology of Organizations, Vol. 52). Bingley: Emerald.

Crozier, M., \& Friedberg, E. (1980). Actors and systems. The politics of collective. Chicago: University of Chicago Press.

de Rijcke, S., Wouters, P. F., Rushforth, A. D., Franssen, T. P., Hammarfelt, B., et al. (2016). Evaluation practices and effects of indicator use - A literature review. Research Evaluation, 25(2), 161-169.

Desrosières, A. (2000). Measurement and its uses: Harmonization and quality in social statistics. International Statistical Review, 68(2), 173-187.

Diaz-Bone, R. (2011). The methodological standpoint of the "économie des conventions". Historical Social Research, 36(4), 43-63.

Diaz-Bone, R. (2017). Discourses, conventions, and critique - perspectives of the institutionalist approach of the economics of convention. Historical Social Research, 42(3), 79-96.

Espeland, W. N., \& Sauder, M. (2007). Rankings and reactivity: How public measures recreate social worlds. American Journal of Sociology, 113, 1-40.

Fourcade, M. (2011). Cents and sensibility: Economic valuation and the nature of 'Nature'. American Journal of Sociology, 116(6), 1721-1777.

GFSO - German Federal Statistical Office. (2008). Monetäre hochschulstatistische Kennzahlen (Fachserie 11, Reihe 4.3.2). Wiesbaden.

GFSO - German Federal Statistical Office. (2009). Personal an Hochschulen (Fachserie 11 Reihe 4.4). Wiesbaden.

GFSO - German Federal Statistical Office. (2015). Monetäre hochschulstatistische Kennzahlen (Fachserie 11, Reihe 4.3.2). Wiesbaden.

GFSO - German Federal Statistical Office. (2016a). Wissenschaftliches Personal nach Hochschulen und Fächergruppen 2007 und 2014 (H201 Sonderauswertung). Wiesbaden.

GFSO - German Federal Statistical Office. (2016b). Personal an Hochschulen (Fachserie 11 Reihe 4.4). Wiesbaden. 
GFSO - German Federal Statistical Office (2017a). Studierende an Hochschulen im Wintersemester 2017/2018 (Fachserie 11 Reihe 4.1). Wiesbaden.

GFSO - German Federal Statistical Office. (2017b). Finanzen und Steuern. Ausgaben, Einnahmen und Personal der öffentlichen und öffentlich geförderten Einrichtungen für Wissenschaft, Forschung und Entwicklung (Fachserie 14, Reihe 3.6). Wiesbaden.

GFSO - German Federal Statistical Office. (2018a). Absolventen nach einzelnen Hochschulen und Fächergruppen vom Prüfungsjahr 1993 bis 2015 (H201 Sonderauswertung). Wiesbaden.

GFSO - German Federal Statistical Office. (2018b). Drittmittel nach Hochschule 2007 und 2014 (H201 Sonderauswertung). Wiesbaden.

Hänseroth, T., \& Mauersberger, K. (1998). Technikwissenschaften zwischen theoretischer Erkenntnis und Ingenieurtätigkeit. NTM Zeitschrift für Geschichte der Wissenschaften, Technik und Medizin, 6(1), 217-237.

Hartmann, M. (2010). Die Exzellenzinitiative und ihre Folgen. Leviathan, 38, 369-387.

Hazelkorn, E. (2015). Rankings and the reshaping of higher education. The battle for world-class excellence (2nd ed.). Basingstoke: Palgrave Macmillan.

Heintz, B. (2016). Wir leben im Zeitalter der Vergleichung. Perspektiven einer Soziologie des Vergleichs. Zeitschrift für Soziologie, 45(5), 305-323.

Hesse. (2004). Gesetz, zur organisatorischen Fortentwicklung der Technischen Universität Darmstadt (TUD-Gesetz). 5. Dezember 2004 (Stand 30. November 2015). Wiesbaden.

Heublein, U., Ebert, J., Hutzsch, C., Isleib, S., König, R., Richter, J., Woisch, A., et al. (2017). Zwischen Studienerwartungen und Studienwirklichkeit (DZHW Forum Hochschule 1/2017). Hannover.

Honneth, A. (2010). Dissolutions of the social: On the social theory of Luc Boltanski and Laurent Thévenot. Constellations, 17(3), 376-389.

Jagd, S. (2011). Pragmatic sociology and competing orders of worth in organizations. European Journal of Social Theory, 14(3), 343-359.

Kehm, B. M. (2013). To be or not to be? The impacts of the excellence initiative on the German system of higher education. In J. C. Shin \& B. M. Kehm (Eds.), Institutionalization of worldclass university in global competition (pp. 81-97). Dordrecht: Springer.

Kunle, H., \& Fuchs, S. (Eds.). (2000). Die Technische Universität an der Schwelle zum 21. Jahrhundert: Festschrift zum 175jährigen Jubiläum der Universität Karlsruhe (TH). Berlin/ Heidelberg: Springer.

Lamont, M. (2012). Toward a comparative sociology of valuation and evaluation. Annual Review of Sociology, 38, 201-221.

Laudel, G. (2006). The 'Quality Myth':promoting and hindering conditions for acquiring research funds. Higher Education, 52(3), 375-403.

Leahey, E. (2007). Not by productivity alone: How visibility and specialization contribute to academic earnings. American Sociological Review, 72(4), 533-561.

Lemieux, C. (2014). The moral idealism of ordinary people as a sociological challenge: Reflections on the French reception of Luc Boltanski and Laurent Thévenot's On Justification. In S. Susen \& B. S. Turner (Eds.), The spirit of Luc Boltanski: Essays on the 'Pragmatic sociology of Critique' (pp. 153-172). London: Anthem Press.

Mau, S. (2018). Das metrische Wir. In Über die Quantifizierung des Sozialen. Frankfurt: Suhrkamp.

Merton, R. K. (1968). The Matthew effect in science. Science, 159(3810), 56-63.

Munch, R. (2013). Academic Capitalism: Universities in the global struggle for excellence. New York: Routledge.

Münch, R. (2015). Science in the hands of strategic management: The metrification of scientific work and its impact on the evolution of knowledge. In I. M. Welpe, J. Wollersheim, S. Ringelhan, \& M. Osterloh (Eds.), Incentives and performance. Governance of research organizations (pp. 33-48). Cham: Springer.

Orr, D., Jaeger, M., Schwarzenberger, A., et al. (2007). Performance-based funding as an instrument of competition in German higher education. Journal of Higher Education Policy and Management, 29(1), 3-23. 
Powell, W. W., \& Di Maggio, P. J. (Eds.). (1991). The new institutionalism in organizational analysis. Chicago: University of Chicago Press.

Powell, J. J. W., \& Dusdal, J. (2017). Science production in Germany, France, Belgium, and Luxembourg: Comparing the contributions of research universities and institutes to science, technology, engineering, mathematics, and health. Minerva, 55(4), 413-434.

Power, M. (1999). The audit society. Rituals of verification. Oxford: Oxford University Press.

Robertson-von Trotha, C. Y. (2009). Schlüsselqualifikationen für Studium, Beruf und Gesellschaft. In Technische Universitäten im Kontext der Kompetenzdiskussion. Karlsruhe: KIT Scientific Publishing.

Saxony-Anhalt. (2010). Hochschulgesetz des Landes Sachsen-Anhalt (HSG LSA) in der Fassung der Bekanntmachung vom 14. Dezember 2010.

Schimank, U., \& Winnes, M. (2000). Beyond Humboldt? The relationship between teaching and research in European university systems. Science and Public Policy, 27, 397-408.

Scott, W. R. (2014). Institutions and organizations ideas, interests, and identities (4th ed.). Thousand Oaks: Sage.

Sieweke, J., Muck, J., Süß, S., Haucap, J., et al. (2014). Forschungsevaluation an Universitäten Ergebnisse einer explorativen Studie rechts- und wirtschaftswissenschaftlicher Fakultäten. Schmalenbachs Zeitschrift für betriebswirtschaftliche Forschung, 66(4), 274-305.

Thévenot, L. (1984). Rules and implements: Investment in forms. Social Science Information, 23(1), 1-45.

Thévenot, L. (2001). Organized complexity. Conventions of coordination and the composition of economic arrangements. European Journal of Social Theory, 4, 405-425.

Thévenot, L., Moody, M., Lafaye, C., et al. (2000). Forms of valuing nature. In M. Lamont \& L. Thévenot (Eds.), Rethinking comparative cultural sociology (pp. 229-272). Cambridge: Cambridge University Press.

Vatin, F. (2013). Valuation as evaluating and valorizing. Valuation Studies, 1(1), 31-50.

Open Access This chapter is licensed under the terms of the Creative Commons Attribution 4.0 International License (http://creativecommons.org/licenses/by/4.0/), which permits use, sharing, adaptation, distribution and reproduction in any medium or format, as long as you give appropriate credit to the original author(s) and the source, provide a link to the Creative Commons license and indicate if changes were made.

The images or other third party material in this chapter are included in the chapter's Creative Commons license, unless indicated otherwise in a credit line to the material. If material is not included in the chapter's Creative Commons license and your intended use is not permitted by statutory regulation or exceeds the permitted use, you will need to obtain permission directly from the copyright holder.

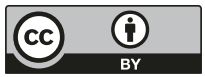

